\title{
HIV Transmission
}

\author{
George M. Shaw ${ }^{1}$ and Eric Hunter ${ }^{2}$ \\ ${ }^{1}$ Department of Medicine, Perelman School of Medicine, University of Pennsylvania, Philadelphia, \\ Pennsylvania 19104 \\ ${ }^{2}$ Department of Pathology and Laboratory Medicine, Emory Vaccine Center, Emory University, \\ Atlanta, Georgia 30329 \\ Correspondence: ehunte4@emory.edu
}

HIV-1 is transmitted by sexual contact across mucosal surfaces, by maternal-infant exposure, and by percutaneous inoculation. For reasons that are still incompletely understood, CCR5tropic viruses (R5 viruses) are preferentially transmitted by all routes. Transmission is followed by an orderly appearance of viral and host markers of infection in the blood plasma. In the acute phase of infection, HIV-1 replicates exponentially and diversifies randomly, allowing for an unambiguous molecular identification of transmitted/founder virus genomes and a precise characterization of the population bottleneck to virus transmission. Sexual transmission of HIV-1 most often results in productive clinical infection arising from a single virus, highlighting the extreme bottleneck and inherent inefficiency in virus transmission. It remains to be determined if HIV-1 transmission is largely a stochastic process whereby any reasonably fit R5 virus can be transmitted or if there are features of transmitted/founder viruses that facilitate their transmission in a biologically meaningful way. Human tissue explant models of HIV-1 infection and animal models of SIV/SHIV/HIV-1 transmission, coupled with new challenge virus strains that more closely reflect transmitted/founder viruses, have the potential to elucidate fundamental mechanisms in HIV-1 transmission relevant to vaccine design and other prevention strategies.

$\mathrm{H}_{\mathrm{s}}^{\mathrm{n}}$ IV-1 transmission results from virus exposure at mucosal surfaces or from percutaneous inoculation. Because such exposures in humans are inaccessible to direct analysis, our understanding of the transmission event must necessarily come from insights gleaned from studies of HIV-1 epidemiology, viral and host genetics, risk factor and behavior analyses, animal models, human explant tissues, and in vitro studies of virus-target cell interactions. In this article, we explore themes that connect these varied aspects of HIV-1 infection with the ultimate goal of understanding the molecular basis of HIV-1 transmission.

\section{EPIDEMIOLOGY OF HIV-1: IMPLICATIONS FOR TRANSMISSION BIOLOGY}

At the broadest level, HIV-1 transmission must be viewed in the context of the global pandemic. Population level phylogenetic patterns of endemic, epidemic, and pandemic strains of HIV-1 can provide insight into clinically relevant aspects of virus transmission. HIV-1 is

Editors: Frederic D. Bushman, Gary J. Nabel, and Ronald Swanstrom

Additional Perspectives on HIV available at www.perspectivesinmedicine.org

Copyright (C) 2012 Cold Spring Harbor Laboratory Press; all rights reserved; doi: 10.1101/cshperspect.a006965

Cite this article as Cold Spring Harb Perspect Med 2012;2:a006965 
classified phylogenetically into groups $\mathrm{M}, \mathrm{N}, \mathrm{O}$, and $\mathrm{P}$, each reflecting a separate introduction of simian immunodeficiency viruses (SIVs) from naturally infected great apes into humans (see Sharp and Hahn 2011). Of these, only group $\mathrm{M}$ underwent pandemic spread. Viral and host factors that may have influenced the relative transmissibility of the different HIV-1 groups are discussed elsewhere (Malim and Bieniasz 2011; Sharp and Hahn 2011). For group M viruses, mathematical modeling of virus diversification suggests a most recent common ancestor near 1910-1930 (Korber et al. 2000; Worobey et al. 2008), followed by subclinical endemic spread of the virus in human populations in West Central Africa. There, largely as a consequence of founder effects and viral population bottlenecks, HIV-1 emerged as early as the late 1950 s as phylogenetically distinct subtypes, of which nine (subtypes A, B, C, D, F, G, H, J, K) are now recognized as contributing to the global pandemic (Taylor et al. 2008).

The extraordinary sequence diversity within and among these different HIV-1 group $M$ subtypes, which can reach $25 \%-35 \%$ in env, has made possible a precise tracking of HIV-1 transmission within and between populations on a global scale (Gilbert et al. 2007; Taylor et al. 2008) and between individuals on a micro scale (Derdeyn et al. 2004; Haaland et al. 2009). A global survey of the distribution of HIV-1 subtypes and intersubtype circulating recombinant forms (CRFs) in 2004 revealed that subtype $\mathrm{C}$ accounted for $50 \%$ of infections worldwide, with subtypes A, B, D, and G accounting for $12 \%, 10 \%, 3 \%$, and $6 \%$, respectively, and subtypes $\mathrm{F}, \mathrm{H}, \mathrm{J}$, and $\mathrm{K}$ together accounting for 1\% (Hemelaar et al. 2006). The global distribution and genetic complexity of HIV-1 subtypes and CRFs have continued to evolve (Taylor et al. 2008), and with this has come the potential for virus evolution, adaptation, and altered transmissibility. Despite this fertile environment for mutation, there is little evidence for meaningful differences among HIV-1 subtypes in their patterns or efficiencies of transmission. The best example of differences in transmission probability is for CRF01_AE in injection drug users (IDUs) in Thailand, which increased substantially in prevalence between 1995-1998 compared with subtype B viruses. Yet, it is unclear whether epidemiological factors, host factors, or viral properties were responsible (Hudgens et al. 2002). There is also an epidemiological observation that subtype $\mathrm{D}$ viruses from Uganda and neighboring regions may show $\mathrm{R} 5 / \mathrm{X} 4$ dual tropism more commonly than do other HIV-1 subtypes, but this may have a greater effect on viral pathogenesis than on transmission per se (Church et al. 2010). Thus, unlike influenza virus in which ongoing genetic mutation dramatically impacts the frequency and patterns of virus transmission, such is not the case for pandemic HIV-1 group $\mathrm{M}$ viruses, which have been remarkably consistent in their transmissibility over expanses of time, geography, and target populations (Taylor et al. 2008) and as the virus moved between individuals and groups of individuals with widely different risk behavior and virus transmission routes (Kouyos et al. 2010).

\section{TRANSMISSION ROUTES AND RISKS FOR HIV-1 INFECTION}

In 2009, an estimated 2.6 million people globally became newly infected by HIV-1 (UNAIDS 2010). This represents a reduction in new infections by $21 \%$ compared with 1997 when incident infections peaked. But declining HIV-1 incidence rates have not been uniform across all regions and risk groups, highlighting the importance of different transmission routes and risk behaviors in facilitating HIV-1 transmission. The most extreme example is in Eastern Europe and Central Asia where HIV-1 prevalence tripled between 2001-2009 as a consequence of concentrated epidemics associated with sex work, drug use, and men who have sex with men (MSM) (UNAIDS 2010). Table 1 summarizes the risks for HIV-1 transmission associated with different transmission routes and their relative contributions to HIV-1 prevalence worldwide. What is evident from these estimates is that heterosexual transmission is responsible for nearly $70 \%$ of HIV-1 infections worldwide with the remainder largely attributable to MSM, maternal-infant infection, and 
HIV Transmission

Table 1. Transmission routes and risks for HIV-1 infection

\begin{tabular}{|c|c|c|c|c|c|}
\hline $\begin{array}{l}\text { HIV invasion } \\
\text { site }\end{array}$ & $\begin{array}{l}\text { Anatomical } \\
\text { sublocation }\end{array}$ & Type of epithelium & $\begin{array}{l}\text { Transmission } \\
\text { medium }\end{array}$ & $\begin{array}{l}\text { Transmission } \\
\text { probability per } \\
\text { exposure event }\end{array}$ & $\begin{array}{l}\text { Estimated } \\
\text { contribution } \\
\text { to HIV cases } \\
\text { worldwide }\end{array}$ \\
\hline \multirow{4}{*}{$\begin{array}{l}\text { Female } \\
\text { genital } \\
\text { tract }\end{array}$} & Vagina & $\begin{array}{l}\text { Squamous, } \\
\text { nonkeratinized }\end{array}$ & Semen; blood & $\begin{array}{l}1 \text { in } 200-1 \text { in } \\
2000\end{array}$ & 12.6 million \\
\hline & Ectocervix & $\begin{array}{l}\text { Squamous, } \\
\text { nonkeratinized }\end{array}$ & & & \\
\hline & Endocervix & Columnar, single layer & & & \\
\hline & Other & Various & & & \\
\hline \multirow[t]{3}{*}{$\begin{array}{l}\text { Male genital } \\
\text { tract }\end{array}$} & $\begin{array}{l}\text { Inner } \\
\text { foreskin }\end{array}$ & $\begin{array}{l}\text { Squamous, poorly } \\
\text { keratinized }\end{array}$ & $\begin{array}{l}\text { Cervicovaginal } \\
\text { and rectal } \\
\text { secretions; } \\
\text { blood }\end{array}$ & $\begin{array}{l}1 \text { in } 700-1 \text { in } \\
3000\end{array}$ & 10.2 million $^{\mathrm{a}}$ \\
\hline & $\begin{array}{l}\text { Penile } \\
\text { urethra }\end{array}$ & Columnar, stratified & & & \\
\hline & Other & Various & & & \\
\hline \multirow{4}{*}{$\begin{array}{l}\text { Intestinal } \\
\text { tract }\end{array}$} & Rectum & Columnar, single layer & Semen; blood & 1 in $20-1$ in 300 & 3.9 million $^{\mathrm{b}}$ \\
\hline & $\begin{array}{l}\text { Upper GI } \\
\text { tract }\end{array}$ & Various & Semen; blood & 1 in 2500 & 1.5 million \\
\hline & & & $\begin{array}{l}\text { Maternal blood, } \\
\text { genital } \\
\text { secretions } \\
\text { (intrapartum) }\end{array}$ & 1 in $5-1$ in 10 & $960,000^{c}$ \\
\hline & & & Breast milk & 1 in $5-1$ in 10 & $960,000^{\mathrm{c}}$ \\
\hline Placenta & $\begin{array}{l}\text { Chorionic } \\
\text { villi }\end{array}$ & $\begin{array}{l}\text { Two-layer epithelium } \\
\text { (cyto- and } \\
\text { syncytiotrophoblast) }\end{array}$ & $\begin{array}{l}\text { Maternal blood } \\
\quad \text { (intrauterine) }\end{array}$ & 1 in $10-1$ in 20 & $480,000^{\mathrm{c}}$ \\
\hline Bloodstream & & & $\begin{array}{l}\text { Blood products, } \\
\text { sharps }\end{array}$ & $\begin{array}{l}95 \text { in } 100-1 \text { in } \\
150\end{array}$ & 2.6 million $^{\mathrm{d}}$ \\
\hline
\end{tabular}

Adapted from the 2010 UNAIDS/WHO AIDS epidemic update and Hladik and McElrath (2008).

${ }^{\mathrm{a}}$ Includes men having sex with men (MSM), bisexual men, and heterosexual men.

${ }^{\mathrm{b}}$ Includes MSM, bisexual men, and women infected via anal receptive intercourse.

${ }^{\mathrm{c}}$ Mother-to-child transmission.

${ }^{\mathrm{d}}$ Mostly intravenous drug use, but includes infections by transfusions and health-care-related accidents. GI, gastrointestinal.

injection drug use. This is the case despite the fact that transmission probability per coital act is lowest for heterosexual exposures ( 1 in $200-$ 1 in 3000) (Hladik and McElrath 2008; McElrath et al. 2008). However, two recent metaanalyses of HIV-1 incidence and prevalence data (Powers et al. 2008; Boily et al. 2009) suggest a far wider range in HIV-1 transmission risk for heterosexual exposures depending on confounding risk factors such as genital ulcer disease, male circumcision, HIV disease stage, and exposure route. For example, penile-vaginal transmission of HIV-1 was reported at a frequency as high as 1 in 10 exposures and penile-anal transmission as high as 1 in 3 depending on confounding risk cofactors (Powers et al. 2008). Thus, the commonly quoted risk estimate for heterosexual HIV-1 acquisition of 1 in 1000 exposures must be considered a lower bound. 
Socioeconomic factors can also influence HIV-1 transmission indirectly. El-Sadr and colleagues have suggested that in the United States, the risk of acquiring HIV-1 infection is defined more by a person's "sexual network" than by their individual risk behaviors, with the former influenced primarily by socioeconomic factors (El-Sadr et al. 2010). On a global basis, HIV-1 transmission estimates per coital act vary significantly between high-income countries, where male to female (MTF) transmission estimates are $0.08 \%$ and female to male (FTM) rates are $0.04 \%$, and low-income countries, where MTF and FTM transmission rates are $0.38 \%$ and $0.3 \%$, respectively (Powers et al. 2008; Boily et al. 2009). These differences may in part reflect the relative frequency of HIV serodiscordant couples in the two settings since it has been estimated that they represent the source of a majority of adult infections in many low-income countries (Dunkle et al. 2008).

Viral load $(\mathrm{vL})$ in the transmitting partner plays a major role in determining the risk of HIV-1 transmission from one individual to another. Although vL likely affects all modes of transmission, it has been best characterized in HIV-1 discordant couples, in which as much as a 2.5 -fold increase in transmission was observed for every 10-fold increase in vL (Quinn 2000; Fideli et al. 2001). Moreover, although $v L$ in genital secretions may not correlate directly with that in the blood, partners with plasma vL less than 1000 rarely transmitted to their partners (Quinn et al. 2000; Fideli et al. 2001). The recent observation (HIV Prevention Trials Network Study 052, unpubl.) that antiretroviral treatment of the positive partner of discordant couples can result in a $96 \%$ reduction in transmission is consistent with this finding (Cohen et al. 2011b). The clinical stage of infection (acute vs. middle vs. late) in the transmitting partner can also play a key role in defining the efficiency of transmission, with the risk of infection from individuals with acute or early infection being higher than that in established infection (Wawer et al. 2005; Brenner et al. 2007; Powers et al. 2008; Miller et al. 2010). This likely reflects the high vLs observed in acute infection, a lack of neutralizing antibodies that may inactivate circulating virus in established infection, and clonal amplification of highly fit viruses in acute infection that are especially suitable for initiating productive infection (Richman et al. 2003; Wei et al. 2003; Wawer et al. 2005; Keele et al. 2008; Cohen et al. 2011a). Indeed, in the Indian rhesus macaque model of SIV transmission, SIV in the plasma from animals in the acute stage of infection had a specific infectivity up to 750 times greater than that of virus in the plasma from chronically infected animals (Ma et al. 2009).

The efficiency of HIV-1 transmission can be modulated by still other factors, including sexually transmitted diseases, particularly those that result in genital inflammation and ulcers, which can elevate HIV shedding into the genital tract and can increase infection susceptibility by two- to 11-fold (Galvin and Cohen 2004); pregnancy, during which a greater than twofold increase in HIV acquisition risk has been observed (Gray et al. 2005); and circumcision, which in a series of clinical trials has been shown to decrease transmission acquisition risk in the male partner by $60 \%$ (Auvert et al. 2005; Bailey et al. 2007; Gray et al. 2007; Quinn 2007).

\section{THE CLINICAL TRANSMISSION EVENT AND ACUTE HIV-1 INFECTION}

Despite the many routes by which HIV-1 can be transmitted from one individual to another, there is generally an orderly and reproducible appearance in the blood of viral and host markers of infection following a clinically productive transmission event (Fig. 1). This sequential appearance of laboratory markers of new HIV-1 infection was systematically evaluated by Fiebig and colleagues who devised a laboratory staging system for acute and early infection (Fiebig et al. 2003). The initial period between the moment when the first cell is infected and when virus is first detectable in the blood is termed the eclipse phase. The duration of this period has been estimated to be approximately 7-21 d, based on clinical histories of high risk exposure events (Gaines et al. 1988; Clark et al. 1991; Schacker et al. 1996; Litthe et al. 1999; Lindback et al. 2000a,b) and 
HIV Transmission

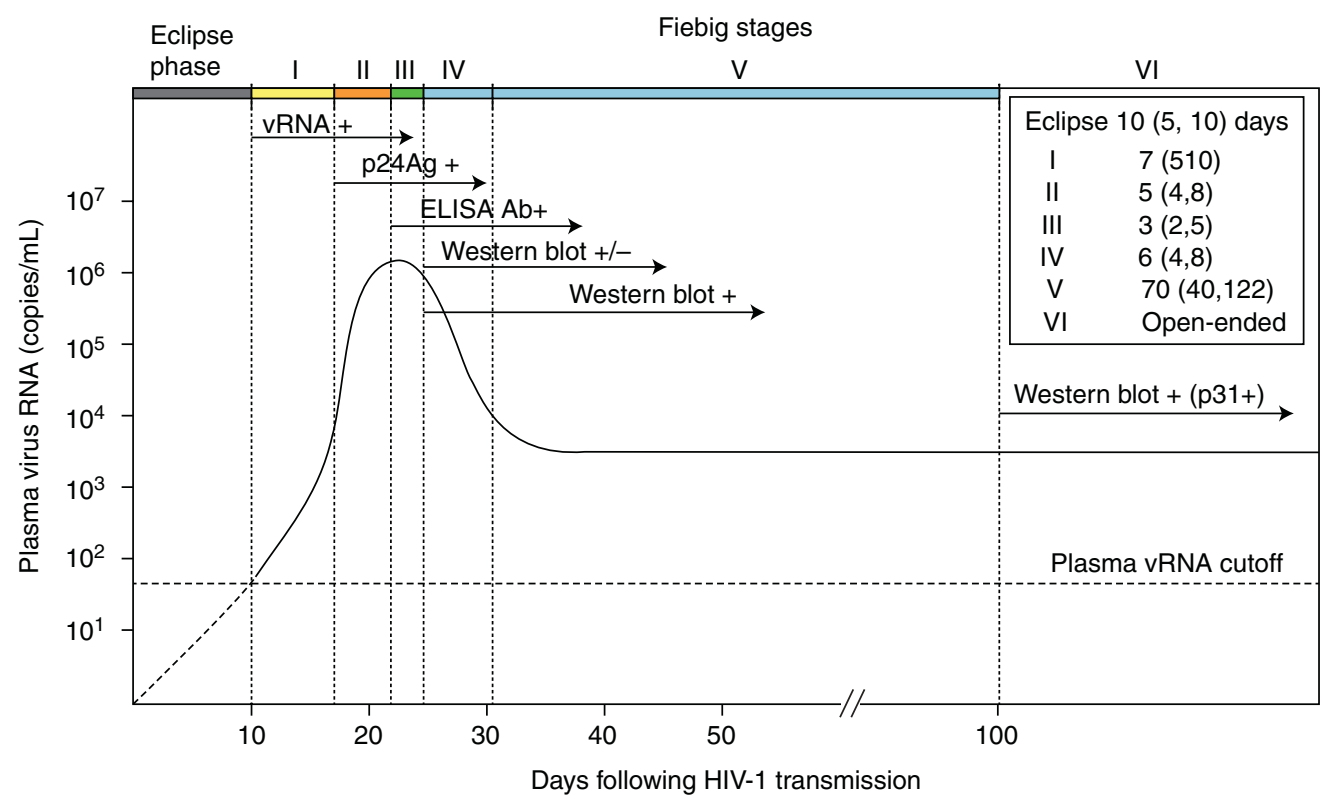

Figure 1. Laboratory staging and natural history of acute and early HIV-1 infection. The average durations and $95 \%$ confidence intervals ( parentheses) of the eclipse phase and Fiebig stages (Fiebig et al. 2003) of acute infection are shown in the inset.

mathematical modeling of early HIV-1 replication and diversification (Keele et al. 2008; Lee et al. 2009). During the eclipse phase, which is clinically silent, virus is propagated in $\mathrm{CD} 4^{+} \mathrm{T}$ cells in mucosa, submucosa, draining lymphatics, and perhaps to a modest extent in gut-associated lymphoid tissue (GALT) and systemic lymphatic tissues (Haase 2010). Once virus becomes detectable in blood plasma, it increases exponentially (Ribeiro et al. 2010) as a consequence of explosive replication in GALT and peripheral lymphoid tissue compartments (Veazey et al. 1998; Guadalupe et al. 2003; Brenchley et al. 2004; Mehandru et al. 2004; Li et al. 2005b; Mattapallil et al. 2005; Haase 2010). Fiebig stages I-VI reflect the ordered appearance in the plasma of HIV-1 viral RNA (Fiebig I), viral p24 antigen (Fiebig II), and virus-specific antibodies detectable first by recombinant protein-based enzyme-linked immunosorbant assay (Fiebig III), and then by Western immunoblotting (indeterminant banding pattern: Fiebig IV; diagnostic banding pattern but missing p31 reactivity: Fiebig V; diagnostic banding pattern with $\mathrm{p} 31$ reactivity: Fiebig VI). The average durations of the eclipse phase and Fiebig stages along with estimated 95\% confidence intervals are shown in the inset of Figure 1. Diagnosing HIV-1 infection as soon as possible after the transmission event is important clinically to ensure the safety of blood for transfusion and of body organs for transplantation. It is also important for preventing forward transmission of the virus from index patients to their contacts. Current HIV-1 nucleic acid tests based on different amplification platforms can detect viral sequences qualitatively at $1-5$ copies per milliliter of plasma (Palmer et al. 2003; Nugent et al. 2009) and quantitatively at levels exceeding 50 copies per milliliter plasma (Damond et al. 2010). Alternatively, a recently approved fourth-generation combined p24 antigen-antibody test can detect HIV-1 at viral loads exceeding 10,000 virions per milliliter plasma (Eshleman et al. 2009; Cohen et al. 2011a). Thus, commercially available p24 antigen tests can detect HIV-1 infection approximately $1 \mathrm{wk}$ before the first detection of 
anti-HIV antibodies, and vRNA tests can detect HIV-1 infection approximately $1 \mathrm{wk}$ before that (Fig. 1). There are well-documented examples of HIV-1 antibody seroconversion as late as 6 mo or more after an exposure event but such cases are rare (Ridzon et al. 1997); what is more remarkable is the consistency in the timing of appearance of viral and host markers of infection (Fig. 1) despite the different cells and tissues that are involved in the transmission process at the different sites of HIV-1 invasion (Table 1).

\section{A POPULATION BOTTLENECK TO HIV-1 TRANSMISSION}

The concept that transmission of HIV involves a population bottleneck, in which a limited number of variants from a genetically diverse virus quasispecies in the transmitting partner establishes productive infection in the newly infected partner, was first established nearly two decades ago (Wolfs et al. 1992; Wolinsky et al. 1992; Zhang et al. 1993; Zhu et al. 1993). These early findings were of particular interest to investigators involved in HIV-1 vaccine research and to those interested in HIV-1 transmission biology, pathogenesis, and natural history because they raised the possibility that selective pressures could be at play in virus transmission. This idea was strengthened by the subsequent discovery of CCR5 and CXCR4 as obligate coreceptors for HIV-1 entry into cells, by the finding of a strong preference for CCR5 use by HIV-1 strains from acute and early infection, and by the observation that humans who are homozygous defective for CCR5 expression are protected from HIV-1 infection (see Berger et al. 1999; Wilen et al. 2011b). Subsequent studies continued to explore the quasispecies complexity and genetic and biologic composition of HIV-1 in acutely infected individuals in an attempt to better define the features of transmitted viruses and cofactors that enhance the risk of transmission (Poss et al. 1995; Zhu et al. 1996; Long et al. 2000; Learn et al. 2002; Derdeyn et al. 2004; Grobler et al. 2004; Ritola et al. 2004; Sagar et al. 2004, 2009). The results of all of these studies, together with the earlier work, led to the concept that whereas chronically infected subjects were invariably infected by a genetically diverse viral quasispecies, acutely infected individuals could be grouped into those with relatively "homogeneous" infections, presumably resulting from transmission and productive clinical infection by one or few closely related viruses, and those individuals with more "heterogeneous" infections that resulted from transmission of multiple viruses with greater diversity. This distinction between homogeneous and heterogeneous virus diversity in acute HIV-1 infection was for the most part a qualitative description, which was further confounded by the suggestion that acutely infected individuals could harbor genetically diverse HIV-1 genotypes that in the weeks following transmission underwent purifying selection so as to give the appearance of a homogeneous acute infection (Learn et al. 2002). Thus, although it was clear that there was a population bottleneck to HIV-1 transmission, a quantitative and molecularly precise description of this bottleneck was not possible. This led to more controversy than consensus regarding the multiplicity of HIV-1 infection in different patient populations with distinct demographic and behavioral risk profiles as well as the genetic and biological properties of such viruses.

The stimulus to a more focused examination of the genotype and phenotypic properties of the viruses that initiate new HIV-1 infections was prompted by a report by Derdeyn and colleagues (2004), which combined an extensive phylogenetic comparison of viral env sequences in chronically infected subjects and their newly infected sexual partners with a phenotypic analysis of viruses pseudotyped by the encoded chronic and acute Env proteins. This study suggested that one or a few virus variants initiated infection in most of the cases examined and that such viruses differed in a consistent way from the bulk of the viruses in the chronicallyinfected partner's viral quasispecies. With an obvious need to further clarify the molecular and biological features of transmitted viruses, Keele and colleagues (2008) devised a novel experimental sequencing strategy to enable a more 
precise molecular identification and enumeration of transmitted HIV-1 genomes. This new approach was based on single-genome amplification (SGA) of endpoint-diluted plasma vRNA/ cDNA or peripheral blood mononuclear cell (PBMC) DNA followed by direct population sequencing of the uncloned DNA amplicon. Sequences were then analyzed phylogenetically in the context of a mathematical model of exponential virus growth and random virus evolution so as to identify actual transmitted/ founder viral genomes that were responsible for productive clinical infection (Keele et al. 2008; Salazar-Gonzalez et al. 2008; Lee et al. 2009). This SGA approach had several key advantages over previous methods: First, SGA-direct sequencing eliminates Taq polymerase errors in finished sequences because such base substitutions are essentially random in distribution and any one substitution is present in exceedingly low proportions in the uncloned amplified product; because the amplified product is directly sequenced, such mutations are not evident on sequence chromatograms unless they occur in the initial polymerase chain reaction (PCR) amplification cycles, in which case they are identified as "double peaks" and the sequence is disregarded. Second, SGA eliminates both template switching (recombination) between genetically distinct viral genomes and template resampling, because amplification is initiated from single genomes. Third, SGA-direct sequencing avoids misrepresentation of target sequence frequencies because of unequal cloning.

SGA-direct amplicon sequencing was thus applied in rapid succession to a large number of clinical cohorts of individuals acutely infected by HIV-1 subtypes A, B, C, D, CRF01_AE, and others. In the first large cohort study of 102 subjects with acute HIV-1 subtype B infection, SGA-direct amplicon sequences of 3449 complete env gp160 genes from plasma vRNA/ cDNA were generated (Keele et al. 2008). A key feature of this study was the categorization of study subjects by Fiebig staging (Fig. 1), which allowed for a systematic analysis of HIV-1 sequence diversification in the earliest phases of acute infection. Sequences showed discrete low-diversity lineages representing the progeny of distinct transmitted viral genomes. Sequences generally showed a Poisson distribution of mutations and star-like phylogeny that coalesced to unambiguous transmitted/founder genomes at or near the moment of virus transmission. This was true for subjects who acquired their infection by any of several routes including vaginal, rectal, penile, or intravenous transmission. Sequences evolved over time consistent with the Poisson distribution and a model that accounted for exponential virus growth, reproductive ratio, virus generation time, and reverse transcriptase error rate estimated for HIV-1 (Lee et al. 2009). This, in turn, allowed for estimates of time to a most recent common ancestor for all sequences. By this approach, a precise molecular identification and enumeration of transmitted/founder virus genomes was obtained for 98 of 102 consecutively studied subjects. Seventy-eight of 102 subjects had evidence of productive clinical infection by a single virus, and 24 subjects had evidence of acute infection by a minimum of two to five genetically distinct viruses from a single partner. Since this study identified the sequences of full-length transmitted/founder env gp160 genes, these sequences could be molecularly cloned and characterized biologically. The key difference between this approach and previous strategies for analyzing cloned env genes is that in the SGA-direct amplicon sequencing method the cloning step is done after an exact and unambiguous sequence determination of the transmitted/founder env gene has been made. This allows the cloned version of the transmitted/ founder env to be matched exactly with the inferred env sequence of the transmitted/founder virus. This same SGA approach was used in subsequent studies to clone full-length transmitted/founder HIV-1 genomes (Salazar-Gonzalez et al. 2009; Li et al. 2010). Thus, in the initial Keele study (Keele et al. 2008), 55 env genes whose sequences matched exactly with transmitted/founder genes were molecularly cloned, expressed in 293T cells, and used to pseudotype in trans Env-deficient HIV-1 viruses. All Envs were biologically functional with respect to virus entry and all were CD4 dependent. Fifty-four of 55 Envs were CCR5-tropic and 
one was CCR5/CXCR4 dual-tropic. Transmitted/founder Envs showed neutralization sensitivity profiles typical of tier 2 or 3 primary virus strains ( $\mathrm{Li}$ et al. 2005a). Thus, the findings from this study provided new clarity to the quantitative and molecular aspects of HIV-1 transmission.

Based on the empirical findings described by Keele et al. (2008) and the mathematical model of early HIV-1 replication and diversification developed by Korber, Perelson, and colleagues (Keele et al. 2008; Lee et al. 2009), a conceptual framework for describing HIV-1 transmission and early diversification was developed (Fig. 2). Direct evidence in support of this transmission model and the notion that actual transmitted/founder viral genomes could be identified unambiguously by SGA-direct amplicon sequencing came from three additional sets of studies: Indian rhesus macaque monkeys inoculated intra-rectally with lowdose SIVmac251 in which viruses in the inoculum and in newly infected animals were found to be identical in env gene sequences (Keele et al. 2009); human transmission pairs in which HIV-1 env and full-length viral genomic sequences were found to be identical in donors and recipients (Haaland et al. 2009; J. SalazarGonzalez and G. Shaw, unpubl.); and 454 deep sequencing of tens of thousands of plasma vRNA/cDNA HIV-1 genomes from three acutely-infected human subjects, demonstrating productive clinical infection by the same transmitted/founder viruses as identified by SGA-direct amplicon sequencing (Fischer et al. 2010). Of note, the terms "transmitted/founder sequence"

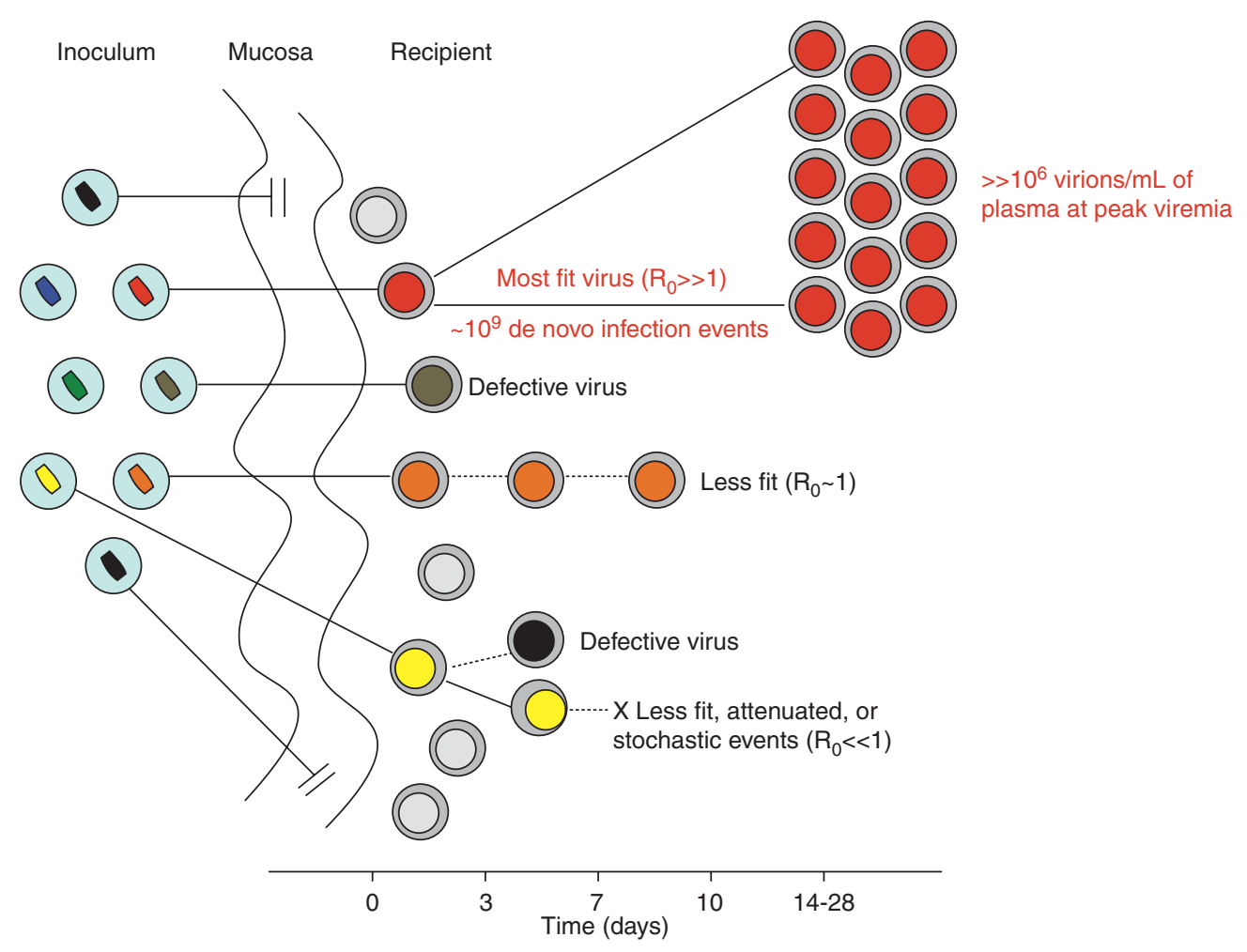

Figure 2. HIV-1 transmission model. HIV-1 virions that breach the mucosa may have different fates. Empirical measurements of virus replication and diversification, together with a mathematical model of random virus evolution, allow for a precise molecular identification of transmitted/founder viruses that are responsible for productive clinical infection (Keele et al. 2008; Lee et al. 2009). $R_{0}$ is the reproductive ratio. $R_{0}>1$ leads to productive clinical infection, whereas $\mathrm{R}_{0}<1$ results in an extinguished infection. 
and "transmitted/founder virus" are used to designate the coalescent or consensus sequence of a low-diversity virus lineage in acutely infected humans or monkeys because such sequences correspond literally to founder sequences that are responsible for establishing productive clinical infection. In most instances, the founder sequence corresponds to the actual transmitted sequence. Exceptions are likely uncommon and include founder sequences that differ from the actual transmitted sequence by one or a few nucleotides because of reverse transcriptase errors in the initial one or two replication cycles or, more substantially, because of recombination between copackaged heterozygous RNA genomes during reverse transcription in the first infected cell (Lee et al. 2009).

Additional studies of acutely infected human cohorts using SGA-direct amplicon sequencing provided further insights into the HIV-1 population bottleneck. These studies focused on heterosexual transmission in subSaharan Africa (Abrahams et al. 2009; Haaland et al. 2009; J Baalwa and G Shaw, unpubl.), MSM transmission in the United States (Kearney et al. 2009; Li et al. 2010), injection drug use transmission in Canada, Russia, and Thailand (Bar et al. 2010; Masharsky et al. 2010; K Bar and G Shaw, unpubl.), and most recently, maternal-infant transmission in Malawi (Russell et al. 2011). Each of these studies provided unambiguous molecular identification of transmitted/founder viral genes or genomes and precise estimates of the numbers of transmitted/founder viruses responsible for productive clinical infection. Two studies used SGA-direct amplicon sequencing to identify full-length transmitted founder genomes (Salazar-Gonzalez et al. 2009; Li et al. 2010). A summary of all of these studies, which included over 300 acutely infected subjects, indicated that approximately $80 \%$ of heterosexual subjects are productively infected by a single viral genome (Keele et al. 2008; Abrahams et al. 2009; Haaland et al. 2009) and approximately 60\% and $40 \%$ of MSM and IDUs, respectively, are productively infected by single genomes. The range in transmitted/founder genomes that resulted in productive clinical infection in these studies was $1-16$, and not surprisingly, the highest numbers were in IDUs (Bar et al. 2010; Li et al. 2010; Masharsky et al. 2010; K Bar and G Shaw, unpubl.). For maternal-infant transmissions, $68 \%$ were productively infected by a single virus and this varied depending on intrauterine versus intrapartum transmission routes (Russell et al. 2011). The observed differences in the multiplicity of viral infection associated with different routes of transmission roughly parallels the relative risk of clinical infection on a per event basis (Table 1). As predicted for transmitted/founder viruses, transmitted/ founder $e n v$ genes were invariably biologically functional and full-length genomes were invariably replication competent (Keele et al. 2008; Salazar-Gonzalez et al. 2009; Li et al. 2010; C Ochsenbauer, J Kappes, and G Shaw, unpubl.). Interestingly, in studies of primarily heterosexual transmission (Keele et al. 2008; Abrahams et al. 2009), in those individuals in which multiple viruses initiated infection, the number of infecting variants did not follow a Poisson distribution. This finding is inconsistent with each variant being transmitted independently and with low probability and suggests that transmission cofactors such as sexually transmitted infections (STIs) or hormonal contraceptives lower the barrier to transmission (Abrahams et al. 2009; Haaland et al. 2009). This interpretation is consistent with the model portrayed in Figure 2, in which virus transmission can fail at multiple steps following inoculation onto a mucosal surface. Thus, STIs including genital ulcer disease may abrogate the barrier imposed by an intact mucosa by inducing breaks in the epithelial lining, thereby allowing more virus variants to initiate infection in the mucosal tissue. Alternatively, inflammation induced by STIs could increase the availability of activated CD4 cells required to initiate a spreading infection, in this way allowing infections that would have failed because of lack of available target cells to expand. Finally, recent SGA comparisons of the genetic diversity of HIV in the genital tract of the transmitting partner to the transmitted/founder virus in the acutely infected partner argue against genital compartmentalization of specific viral 
variants in the donor as being responsible for origin of the population bottleneck, consistent with the model presented in Figure 2 (D Boeras, and E Hunter, unpubl.).

\section{GENETIC SIGNATURES AND PHENOTYPES OF TRANSMITTED/FOUNDER VIRUSES}

The identification and enumeration of transmitted/founder viruses in acutely infected heterosexuals, MSM, IDUs, and infants born to infected mothers provided an opportunity to explore such viruses for genetic signatures and phenotypic properties that might distinguish them from other viruses. Such studies had been undertaken previously with early but not transmitted/founder viruses, and they yielded intriguing findings, but the molecular identification of transmitted/founder viruses allowed for the first time such studies to be undertaken with far greater precision. From earlier studies, it was well established that the transmission of HIV-1 in humans selected for CCR5 tropic viruses, and that R5 viruses could be distinguished from CXCR4-tropic viruses (X4 viruses) genotypically by amino acid "signatures" primarily in the $\mathrm{V} 3$ region of Env (Resch et al. 2001; Jensen et al. 2003). But the important question now raised was if there were additional genetic signatures and corresponding phenotypic properties that distinguish transmitted R5 from others. Put differently, is HIV-1 transmission essentially a stochastic process in which any reasonably fit R5 virus can be transmitted, or are there critical properties of viruses that are transmitted that distinguish them from the innumerable variants that circulate in every chronically infected individual? If such signatures and phenotypes could be identified, they could conceivably represent targets of rational vaccine or drug design.

The first suggestion that HIV-1 transmission might select for traits other than coreceptor usage came from a genetic comparison of the viral env sequences from eight subtype C HIV-1 transmission pairs (Derdeyn et al. 2004). This study was conducted prior to reports describing SGA and thus carries the caveat that molecular clones of env could have contained in vitro generated artifacts from Taq polymerase misincorporation or recombination. Nonetheless, in each subject pair, regardless of whether virus was transmitted MTF or FTM, the newly transmitted viruses encoded statistically shorter and less glycosylated V1V4 regions than did envs from the chronically infected partner. This finding raised the possibility that more compact Env glycoproteins might interact more efficiently with relevant target cells in the genital mucosa. This observation was subsequently confirmed using SGA methods in an independent cohort of 10 subtype $\mathrm{C}$ transmission pairs (Haaland et al 2009). Similar results, albeit with non-SGA methods, were obtained in studies comparing Envs from subtype A HIV-1 acutely infected sex workers to a database of matched chronic virus sequences (Chohan et al. 2005) and 13 subtype D and A transmission pairs from the Rakai district of Uganda (Sagar et al. 2009). Interestingly, such differences in acute versus chronic Envs were not seen in studies of recently transmitted subtype B HIV-1 heterosexual or MSM infections, suggesting that subtype differences in the virus or maturity of the epidemics may influence the contribution of such a phenotype to HIV-1 transmission (Chohan et al. 2005; Frost et al. 2005; Wilen et al. 2011a). Most recently, Korber and colleagues (Gnanakaran et al. 2011) compared over 7000 SGAderived env gp160 sequences from 275 acutely or chronically infected subtype B subjects and observed statistically robust signatures comprising single amino acids, glycosylation motifs, and multisite patterns of clustered amino acids. These included signatures near the CCR5 coreceptor binding surface, near the CD4-binding site, in the cytoplasmic domain of gp41, and in the signal peptide. The motif with highest statistical significance was at amino acid position 12 in the signal peptide, which may affect Env expression and incorporation of Env into virions (Asmal et al. 2011). The second most significant signature was at amino acid position 413-415, which affected a glycan involved in escape from antibody neutralization. How these changes might affect HIV-1 transmission is currently unknown. 
A second approach to analyzing transmitted HIV-1 genomes for distinguishing properties is by phenotypic characterization. It has been difficult to link sequence differences observed between chronic and acute Envs, even within transmission pairs, to a distinct phenotypic property that might influence transmission other than CCR5 tropism. In an analysis of Zambian subtype $\mathrm{C}$ transmission pairs (Derdeyn et al. 2004), it was found that Envs from the newly transmitted viruses retained sensitivity to neutralization by the partner's antibodies and in fact were more sensitive on average than Env variants derived from the transmitting partner (Derdeyn et al. 2004). This characteristic coupled with shorter variable loops in early viruses led to the hypothesis that transmissibility was linked to loss of Env modifications required for neutralization resistance in the chronically infected host but dispensable in the immunologically naïve partner. Despite this, the acute Envs were not generally more sensitive to neutralization by either pooled HIV-1-positive sera or to a majority of broadly neutralizing antibodies (Derdeyn et al. 2004; Li et al. 2006). Moreover, the acute and chronic Envs had similar requirements for high CD4 and CCR5 levels on target cells and they showed comparable utilization of CCR 5 chimeric proteins and alternative coreceptors (Isaacman-Beck et al. 2009; Alexander et al. 2010). Also, following up on genetic signatures of virus transmission identified by Korber and colleagues (Gnanakaran et al. 2011), Asmal et al. (2011) characterized the phenotypic effects of the position 12 polymorphism in the Env leader sequence, which was found to be an enriched motif in transmitted/founder viruses. Experiments showed an association between a positive amino acid (histidine) at position 12 and higher Env expression, higher virion Env incorporation, and higher virion infectivity compared with control viruses.

The first biological analysis of complete HIV-1 subtype B transmitted/founder env genes (Keele et al. 2008), and of subtype B and C transmitted/founder full-length viral genomes (Salazar-Gonzalez et al. 2009; Li et al. 2010), showed these viruses to be uniformly CD4 dependent and CCR5 or CCR5/CXCR4 dual tropic. These findings thus revealed that CCR 5 tropism is a property of the transmitted virus itself and not a phenotype that evolves in the initial days and weeks of infection. Similarly, transmitted/founder viruses were found to show neutralization sensitivity patterns typical of tier 2 or 3 primary virus strains ( $\mathrm{Li}$ et al. 2005a) with V3 and coreceptor binding surface regions well protected from binding by neutralizing monoclonal or polyclonal HIV-1 antibodies (Keele et al. 2008). Again, these were properties of the transmitted/founder virus at or near the moment of virus transmission and were not properties that evolved in early infection. Subtype B and C transmitted/founder genomes encoded viruses that replicated efficiently in primary human $\mathrm{CD}^{+} \mathrm{T}$ cells but much less well in monocyte-derived macrophages (Salazar-Gonzalez et al. 2009; Li et al. 2010; C Ochsenbauer, J Kappes, and G Shaw, unpubl.), consistent with results obtained with Env pseudotyped viruses (Isaacman-Beck et al. 2009). These observations were extended to subtype A transmitted/founder viruses, which replicated efficiently in primary human $\mathrm{CD} 4^{+}$ $\mathrm{T}$ cells but very poorly in monocyte-derived macrophages. Interestingly, a substantial proportion of subtype $\mathrm{D}$ transmitted/founder viruses replicated efficiently in both $\mathrm{CD} 4^{+}$ T cells and macrophages ( $\mathrm{J}$ Baalwa and G Shaw, unpubl.), which may correlate with enhanced neuropathogenesis of subtype $\mathrm{D}$ viruses more generally (Sacktor et al. 2009). Again, these findings described features of transmitted/ founder viruses at or near the moment of transmission and not virus properties that evolved in the newly infected host. Thus, these findings have particular relevance to rational vaccine design efforts and studies of virus transmission in general. With respect to animal models and human tissue explant studies of HIV-1 transmission, the results suggest that tissue macrophages may not play a significant role in HIV-1 transmission and that prototypic macrophage-tropic HIV-1 strains such as BaL, ADA, and YU2 may not be best suited as challenge viruses.

Swanstrom and colleagues (Russell et al. 2011) recently examined the genetic and biological 
basis of the HIV-1 population bottleneck in mother-infant HIV-1 transmission in subtype $\mathrm{C}$ infections in Malawi. They used SGA techniques to characterize 19 transmission pairs, of which 10 involved intrauterine transmission and nine intrapartum transmission. There was a stringent transmission bottleneck in each case. Thirteen of 19 transmissions were estimated to be from a single virus. Intrapartum (but not intrauterine) transmissions were characterized by transmitted/founder Envs that were shorter and had fewer potential amino-linked glycans in V1-V5. Mother and infant viruses were similar, however, in their sensitivity to soluble CD4, a panel of neutralizing monoclonal antibodies, and to autologous and heterologous polyclonal antibody neutralization. Thus, a distinguishing transmission phenotype was not evident.

The most comprehensive and systematic assessment thus far of the biology of transmitted/founder Envs compared with chronic HIV-1 Envs has been conducted by Doms and colleagues (Wilen et al. 2011a). These investigators compared the biological activity of 24 clade B transmitted/founder Envs with that of 17 chronic controls. To increase the likelihood of an intact mucosal barrier in the acutely infected recipients and thus the likelihood of identifying phenotypic properties associated with mucosal transmission, only transmitted/founder Envs from individuals productively infected by a single virus were enrolled in the acute infection arm of the study. Env pseudotyping was used to assess envelope function in single-round infectivity assays to compare coreceptor tropism, CCR5 utilization, primary CD $4^{+}$T-cell subset tropism, dendritic cell trans-infection, Env fusion kinetics, and neutralization sensitivity between acute and chronic Envs. Transmitted/ founder and chronic Envs were phenotypically equivalent in most assays, although transmitted/founder Envs were slightly more sensitive to neutralization by the CD4-binding-site antibodies b12 and VRC01 and by pooled human HIV hyperimmune immunoglobulin (HIVIG). These findings were independently validated using a panel of 14 additional chronic HIV-1 Env controls.
With a relatively large number of transmitted/founder and acute Envs now having been examined across a number of different studies and by different investigative groups, it seems that no single major genetic or phenotypic signature is required for transmission beyond the use of CCR5. Current data suggest that an array of genetic traits, including but not limited to shorter variable loops and reduced numbers of amino-linked glycosylation sites is associated with enhanced virus transmission at least for subtypes A, C, and possibly B. The structural implications of these signatures and of the modestly enhanced neutralization sensitivity of subtype B viruses are not yet understood. However, the possibility exists that relatively subtle alterations of Env structure and function in the context of the native Env trimer could provide sufficient selective advantage during the eclipse phase of HIV-1 transmission to result in preferential transmission of such viruses. The recent finding that HIV-1 gp120 binds to the $\mathrm{CD}^{+} \mathrm{T}$-cell gut homing integrin $\alpha 4 \beta 7$ has raised the possibility that this capacity is important to an infecting virus by targeting cells capable of trafficking to the gutassociated lymphoid tissue (Arthos et al. 2008). It has been reported that $\alpha 4 \beta 7$ highly expressing $\mathrm{CD}^{+} \mathrm{T}$ cells are more susceptible to productive infection by HIV-1 than those expressing low levels of the integrin, in part because this subset is enriched for activated $\mathrm{CD}^{+}$cells, and in part because $\alpha 4 \beta 7 \mathrm{hi}$ cells express high levels of CCR5 and low levels of CXCR4 (Cicala et al. 2009). Interestingly, a small sample of acute subtype $\mathrm{A}$ and $\mathrm{C}$ virus Envs bound $\alpha 4 \beta 7$ with high affinity, and in some cases, later virus strains showed significantly reduced binding (Nawaz et al. 2011), consistent with an early requirement for infection of $\alpha 4 \beta 7$-expressing cells that is dispensable once infection in the gut mucosa has been established. Given that HIV-1 transmission is inherently inefficient and likely represents the most vulnerable point in the natural history of HIV-1 infection, identifying unique properties and potential vulnerabilities of transmitted/founder viruses remains an important objective. 


\section{MODELS OF HIV-1 TRANSMISSION}

Because the eclipse phase of infection and mucosal invasion sites invariably obscure the earliest virus-host interactions, investigators have turned to models of HIV-1 transmission to study the earliest events that initiate productive clinical infection. Figures 1 and 2 illustrate early HIV-1 replication dynamics and diversification along with initial host antibody responses for which there is now substantial direct experimental validation in humans. Figure 3 illustrates early virus-host interactions, many of which are not amenable to direct analysis in humans but which have been studied in human tissue explants and in the primate SIV model of HIV-1 transmission. Importantly, experimental data supporting all three models of $\mathrm{HIV} / \mathrm{SIV}$ replication, diversification, and transmission biology are largely internally consistent and mutually reinforcing and have begun to provide a window on the HIV-1 transmission process not previously possible.

\section{Mathematical Models}

Central to the development and validation of a strategy to identify transmitted/founder virus genomes by SGA, direct amplicon sequencing, and phylogenetic analysis was the development of a mathematical model to describe early virus replication and diversification. This model was developed and refined by Korber, Perelson, and colleagues (Keele et al. 2008; Lee et al. 2009) and used previously estimated parameters of HIV-1 generation time ( $2 \mathrm{~d}$ ), reproductive ratio $\left(R_{o}=6\right)$, and reverse transcriptase error rate $\left(2.16 \times 10^{-5}\right)$ and assumed that initial virus replicates exponentially infecting $R_{o}$ new cells at each generation and diversifying under a model of evolution that assumes no selection. Viruses were predicted to show a Poisson distribution of mutations and a star-like phylogeny. This model led Keele and colleagues (2008) to posit that the progeny of individual transmitted/founder viruses that establish productive clinical infection could thus be identified in acute infection as distinct low-diversity genetic lineages and that the consensus sequence, or coalescent, of each lineage would correspond to actual transmitted/founder viruses. These hypotheses were proven to be valid in both acute HIV-1 and SIV infection (Keele et al. 2008, 2009; Li et al. 2010; Liu et al. 2010; Stone et al. 2010). More recently, Perelson and coworkers developed a stochastic model of the early HIV-1 infection (Pearson et al. 2011), as opposed to deterministic models, to probe the earliest virus-host events following virus inoculation. They distinguish virus that is released from cells continuously versus in a burst and show that these different mechanisms of virus production lead to substantially different early viral dynamics and different probabilities of virus extinction. The stochastic model moves us a step closer to what is believed to be the most vulnerable point in HIV-1 infection, in the hours and days immediately following virus exposure, and provides insights relevant to vaccine and therapeutic interventions at this critical period in the transmission process of HIV-1.

\section{Primate-SIV Infection Models}

The primate-SIV infection model captures many of the essential elements of virus-host interactions illustrated in Figures 1-3. Because more data are available for the primate cervicovaginal infection model, our discussion will be limited to it, although recent work with a penile SIV infection model is promising ( $\mathrm{Ma}$ et al. 2011; Yeh et al. 2011). Although the eclipse phase of mucosal infection by SIVmac251 or SIVsmE660 is generally shorter than the 7$21 \mathrm{~d}$ reported for HIV-1 infection of humans, early SIV replication kinetics in acute SIV infection of macaques is quite comparable with HIV-1 infection of humans (Liu et al. 2010; Stone et al. 2010). In fact, Barouch and colleagues showed that in a low-dose rectal mucosal infection model of Indian rhesus macaques, the eclipse phase lengthens to approximately $7 \mathrm{~d}$ as the multiplicity of infection approaches one virus (Liu et al. 2010). Moreover, the early diversification of mucosally transmitted SIV in macaques is virtually indistinguishable from HIV-1 in humans (Keele 
G.M. Shaw and E. Hunter

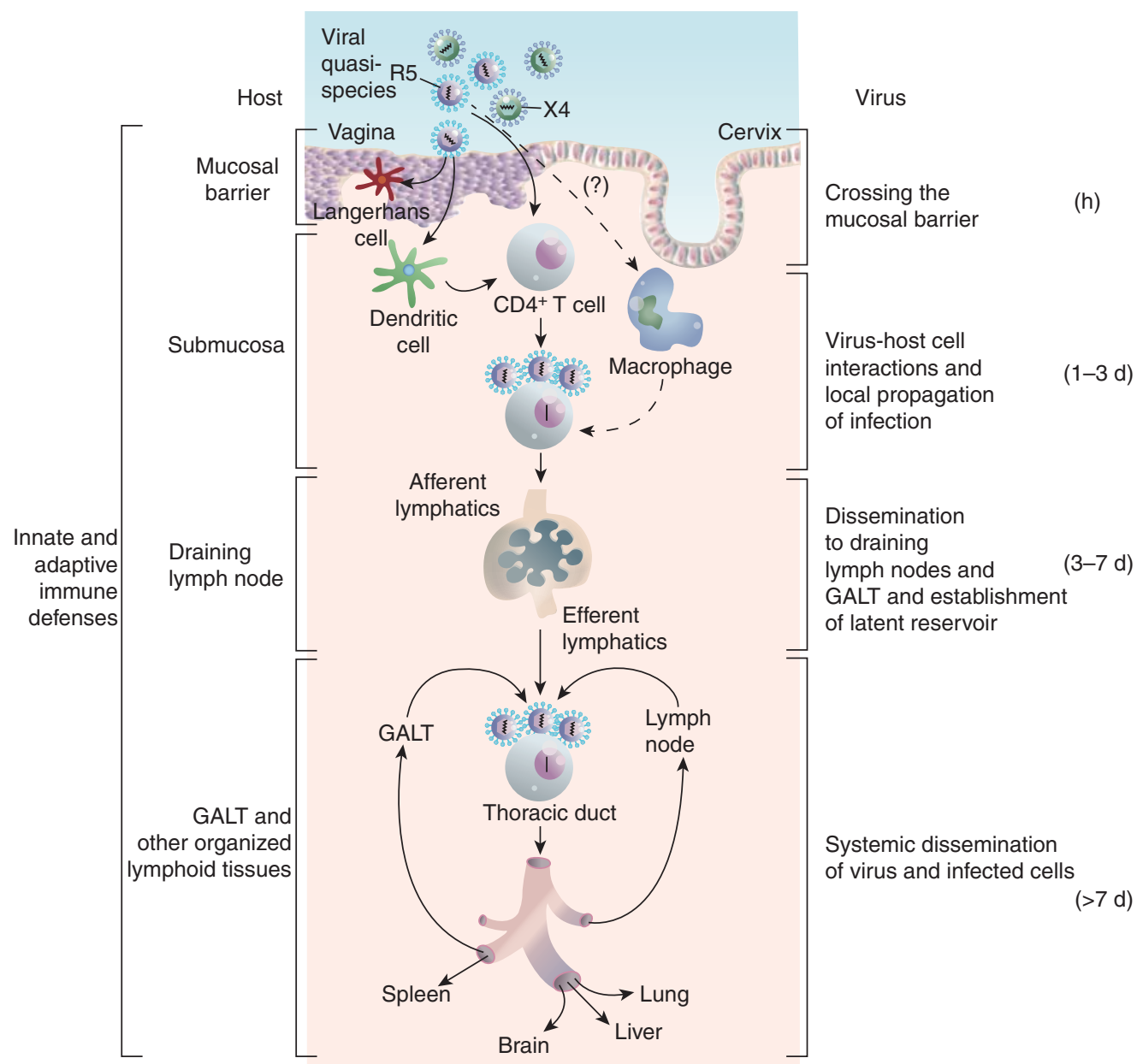

Figure 3. Model of cervicovaginal infection by HIV-1. Preferential R5 HIV-1 transmission is illustrated along with potential roles for Langerhans cells, dendritic cells, and tissue macrophages. Most HIV-1 transmitted/ founder viruses replicate efficiently in $\mathrm{CD}^{+} \mathrm{T}$ cells but not in monocyte-derived macrophages (SalazarGonzalez et al. 2009; Li et al. 2010), raising questions about the role of macrophages in HIV-1 transmission. Virus-host cell interactions in the initial days of infection have been elucidated primarily in the SIV-Indian rhesus macaque infection model (Haase 2010) and in human tissue explants (Hladik and McElrath 2008). (Adapted from Pope and Haase 2003.)

et al. 2008, 2009; Liu et al. 2010; Stone et al. 2010). The virus-host cell interactions believed to underlie HIV-1 transmission based on human tissue explant studies and in vitro analyses of virus-host cell interactions are also generally similar to SIV infection of macaques. Figure 3 represents a mucosal infection model based on a large amount of SIV-rhesus macaque cervicovaginal transmission and infection data, human tissue explant findings, and in vitro analysis of HIV-host cell interactions. SIV can cross mucosal epithelial surfaces within hours (Hu et al. 2000) and infects small numbers of cells productively (Zhang et al. 1999; Miller et al. 2005). In a high-dose mucosal challenge model, the numbers of viruses that cross the epithelial surfaces are great, as are the numbers of initially infected cells (Haase 2010; B Keele, $\mathrm{J}$ Estes, and J Lifson, unpubl.). In low-dose mucosal challenge models, these numbers are 
much smaller and more characteristic of human mucosal infection in which the numbers of transmitted/founder viruses are typically one or few (Keele et al. 2008, 2009; Abrahams et al. 2009; Haaland et al. 2009; Li et al. 2010; Liu et al. 2010; Stone et al. 2010). In macaques, the initial founder populations of productively infected cells undergo rapid expansion and within 1 wk or less, SIV disseminates widely to secondary lymphoid organs including GALT, in which a self-propagating systemic infection is established (Veazey et al. 1998; Miller et al. 2005). Although these events likely have close parallels in human HIV-1 infection, a key difference is that in high-dose mucosal SIV infection, every animal becomes productively infected by generally large numbers of transmitted/founder viruses following a single virus inoculation. In low-dose mucosal SIV infection, only a fraction of animals becomes productively infected following a single inoculation, and then generally by one or a few viruses. In uncomplicated human vaginal exposure to $\mathrm{HIV}-1$, the virus inoculum is effectively still lower, resulting in productive clinical infection in one in every 200-2000 exposed women, and then by a single virion in $80 \%$ of cases (Table 1) (Keele et al. 2008; Abrahams et al. 2009; Haaland et al. 2009). Thus, it is unclear at the present time how closely the in situ virus-host interactions described thus far for the earliest phases of SIV infection of macaques (Haase 2010) correspond to eclipse phase events in human HIV-1 infection. Beyond these earliest events, SIV generally becomes detectable in the blood by the second week of infection and increases exponentially at a rate comparable or even faster than that of HIV-1 in humans (Lifson et al. 1997; Nowak et al. 1997; Ribeiro et al. 2010).

SIV and HIV-1 presumably invade the new host where mucosal surfaces can most easily be breached, and for HIV-1 this can be aided by microabrasions caused by the trauma of sexual intercourse or associated with sexually transmitted diseases or genital ulcerative disease (Abrahams et al. 2009; Haaland et al. 2009). It is of note that hepatitis $\mathrm{C}$ virus (HCV) generally circulates at even higher titers in human plasma than does HIV-1, yet it is exceedingly rare for it to be transmitted by penile-vaginal intercourse-so rare that the U.S. Department of Health and Human Services and Centers for Disease Control do not recommend barrier protection (condoms) to prevent heterosexual transmission of $\mathrm{HCV}$ in discordant couples. This suggests that the mechanism of transmission of HIV-1 across the vaginal and cervical mucosa is fundamentally different from a simple exchange of virus-contaminated blood or blood plasma across an abraded or otherwise traumatized mucosal surface. A single layer of columnar epithelium covers the endocervix and part of the transformation zone between endocervix and ectocervix. The endocervix and transformation zone appear to be preferential but not exclusive sites of HIV-1 entry and early replication ( $\mathrm{Li}$ et al. 2009a). The stratified squamous epithelium of the vagina contains Langerhans cells whose extensions may reach the luminal surface. Langerhans cells are infectable by HIV-1 and can traffic to the submucosa. The submucosa of both the vagina and cervix contain dendritic cells, which also can become infected or transmit HIV-1 to $\mathrm{CD}^{+} \mathrm{T}$ cells (Boggiano and Littman 2007; Boggiano et al. 2007; Hladik et al. 2007).

In macaques, the earliest focal collections of productively infected cells in cervical mucosa and submucosa are $\mathrm{CD} 4^{+} \mathrm{T}$ cells that show a largely "resting" phenotype and low-level CCR5 expression (Zhang et al. 1999, 2004; Li et al. 2005b). In acute HIV-1 infection of humans, "resting" $\mathrm{CD}^{+} \mathrm{T}$ cells also play a substantial role in supporting high-level virus replication (Zhang et al. 1999; Schacker et al. 2001). It is believed that such cells are memory $\mathrm{CD} 4^{+}$ $\mathrm{T}$ cells that have reverted to a largely resting phenotype but have retained sufficient CCR5 and activation pathway molecules to support SIV/HIV replication. This may be accentuated in GALT, in which $\alpha 4 \beta 7$ expression on helper $\mathrm{CD}_{1} 7^{+} / \mathrm{CD}^{+} \mathrm{T}$ cells may facilitate virus infection and replication (Arthos et al. 2008; Kader et al. 2009). Interestingly, tissue macrophages are not a primary target of early SIV infection, consistent with the failure of most transmitted/founder HIV-1 genomes to replicate efficiently in this cell type in vitro 
(Salazar-Gonzalez et al. 2009; Li et al. 2010; C Ochsenbauer, J Kappes, and G Shaw, unpubl.).

Perelson has suggested that mucosal infections by HIV-1, and by analogy SIV, may be extinguished because of stochastic events in the transmission process (Pearson et al. 2011). This could be caused by limitations in target cell availability that may be more significant in cervicovaginal mucosa and submucosa than in rectal tissue (Edwards and Morris 1985; Ma et al. 2001; Zhang et al. 2004; Pudney et al. 2005; Miyake et al. 2006). A complex interplay of early innate host defenses may contribute to early virus containment or elimination, but paradoxically such responses can facilitate transmission by recruiting new potential target cells for infection (Li et al. 2009a; Haase 2010). Once infection disseminates to locoregional lymphatics, the GALT, and other secondary lymphoid tissues, massive depletion of memory $\mathrm{CD}^{+} \mathrm{T}$ cells in the lamina propria ensues (Clayton et al. 1997; Veazey et al. 1998; Guadalupe et al. 2003; Brenchley et al. 2004; Mehandru et al. 2004; Mattapallil et al. 2005; Li et al. 2005b). Massive immune activation, further loss of $\mathrm{CD}^{+}{ }^{+} \mathrm{T}$ cells, and an acute enteropathy commonly follow (Kotler et al. 1984; Heise et al. 1994; Li et al. 2008). Defining critical steps in the mucosal transmission of SIV and HIV-1, including those most vulnerable to therapeutic or immunologic modulation or intervention, remains a high priority. Modulation of immune activation in the SIV-rhesus macaque infection model by glycerol monolaurate represents proof-of-concept of such an approach to prevention ( $\mathrm{Li}$ et al. 2009a). Passive immunization with neutralizing monoclonal antibodies including 2F5, 4E10, 2G12, and B12 in a SHIV infection model provides another important proof-of-concept of the vulnerability of HIV-1 at this critical juncture (Mascola 2002; Hessell et al. 2007, 2009a,b).

\section{Human Tissue Explant Models}

An extensive body of literature describes human tissue explant models and their application to the analysis of HIV-1 and SIV transmission. Much of this has been summarized in recent reviews (Hladik and McElrath 2008; Wira and Veronese 2011). Although increasing attention in recent years has been paid to penile (Fischetti et al. 2009; Dinh et al. 2011) and gastrointestinal (Fletcher et al. 2006; Grivel et al. 2007; Shen et al. 2009, 2010) explant models, most information (Collins et al. 2000; Greenhead et al. 2000; Hu et al. 2004; Maher et al. 2005; Hladik et al. 2007; Saba et al. 2010; Merbah et al. 2011), can be correlated with in situ studies of primate infection by SIV (Haase 2010). Hladik and colleagues (2007) described a human vaginal organ explant culture system that involved the physical separation of vaginal epithelium from underlying stroma. This allowed for an identification of HIV-1 infection of cells exclusively in the epithelium and tracking of these cells as they exited the epithelium into surrounding culture medium. By using confocal fluorescent microscopy, virions were observed to bind and productively infect $\mathrm{CD} 4^{+} \mathrm{CCR} 5^{+}$ CD45RO (memory) $\mathrm{T}$ cells within 2 hours of virus exposure to the intact epithelial surface. Both binding and infection of these cells was dependent on $\mathrm{CD}^{+}{ }^{+} \mathrm{CCR} 5^{+}$engagement by the viral Env glycoprotein and could be blocked by receptor antibodies. HIV-1 also bound to Langerhans cells in the epithelium and localized to a perinuclear intracellular compartment but without evidence of productive infection. Antibody blocking of $\mathrm{CD} 4^{+}$and $\mathrm{CCR} 5^{+}$, and mannan inhibition of C-type lectin binding by Env, did not inhibit Langerhans cell uptake of HIV-1, suggesting alternative pathways of virus binding and uptake by Langerhans cells. As long as $60 \mathrm{~h}$ posttransmission, HIV-1 could be identified in vacuolar compartments of Langerhans cells, which were frequently observed to associate with $\mathrm{CD}^{+} \mathrm{T}$ cells. Whether Langerhans cell $\mathrm{CD}^{+}{ }^{+} \mathrm{T}$-cell associations represented an "immunological synapse" active in virus transmission was not determined. This study thus showed rapid productive infection of human memory $\mathrm{CD}^{+}{ }^{+} \mathrm{T}$ cells consistent with in situ findings in the SIV-macaque infection model (Haase 2010), and internalization and persistence of HIV-1 in Langerhans cells in association with $\mathrm{CD}^{+}{ }^{+} \mathrm{T}$ cells (Fig. 3). Studies by Saba et al. (2010) in a cervicovaginal explant 
model also observed that $\mathrm{CCR} 5^{+} \mathrm{CD} 4^{+} \mathrm{T}$ cells with the effector memory phenotype are a primary target for infection. Human cervicovaginal tissue ex vivo was found to preferentially support productive infection by R5 HIV-1 rather than by X4 HIV-1 despite ample expression of CXCR4. Productive infection by R5 HIV-1 occurred preferentially in activated $\mathrm{CD} 38^{+} \mathrm{CD} 4^{+} \mathrm{T}$ cells in association with activation of HIV-1-uninfected (bystander) $\mathrm{CD}^{+}{ }^{+} \mathrm{T}$ cells that may amplify viral infection. That CXCR4-tropic HIV-1 replicated only in the few tissues that were enriched in $\mathrm{CD} 27^{+} \mathrm{CD} 28^{+}$ effector memory $\mathrm{CD} 4^{+} \mathrm{T}$ cells, if translatable to tissue in vivo, could in part explain the selection of R5 viruses during transmission. Still other human cervical explant studies were conducted by Shattock and colleagues (Greenhead et al. 2000). This work characterized cellular factors involved in HIV-1 entry (Hu et al. 2004) and identified potential therapeutic agents that block infection (Fletcher et al. 2005; Cummins et al. 2007; Buffa et al. 2009). In this model, blockade of CD4 or CCR5/CXCR4 prevented localized mucosal infection and trafficking by dendritic cells.

An extensive ex vivo tissue explant literature thus describes virus-host cell interactions in female and male genital mucosa that may contribute to natural HIV-1 transmission. This work includes descriptions of cell targets, cell surface molecules that mediate virus attachment or infection, and cell signaling pathways that facilitate virus infection and transmission (Hladik and McElrath 2008). However, a key question still unanswered by in vitro cell culture analyses, ex vivo tissue explant studies, or in vivo SIV-macaque infection studies is what is the contribution of Langerhans cells, dendritic cells, or macrophages, compared with $\mathrm{CD} 4^{+}$ $\mathrm{CCR}^{+}{ }^{+} \mathrm{T}$ cells alone to mucosal transmission of HIV-1 (Fig. 3). As this question is revisited, attention to the biological relevance and authenticity of the challenge viruses used in the model systems is warranted. The macrophagetropic HIV-1 BaL, ADA, and YU2 strains, and the T-cell line-adapted NL4.3 and HXB-2 strains, have been used extensively in previous transmission model studies, yet none of these viruses appears to faithfully reflect the properties described thus far for transmitted/founder viruses from acutely infected humans (Keele et al. 2008; Salazar-Gonzalez et al. 2009; Li et al. 2010; Wilen et al. 2011a). Future mucosal transmission studies may benefit from using virus challenge strains that more closely reflect actual transmitted/founder viruses.

\section{CONCLUSIONS}

Interrupting HIV-1 transmission by vaccination, microbicides, pre- or postexposure antiviral drug prophylaxis, or by any of a number of other prevention strategies is of paramount importance in curbing the HIV/AIDS pandemic. Elucidation of molecular viral-host interactions responsible for virus transmission and productive clinical infection can be instrumental in achieving this end. A new strategy for the molecular identification of transmitted/ founder HIV-1 genomes, together with improved tissue explant and in vivo models of HIV-1 transmission, brings the possibility of elucidating critical HIV-1 transmission events and vulnerabilities within reach. Future studies can benefit from building on what has become an increasingly firm foundation in our knowledge of HIV-1 transmission.

\section{REFERENCES}

* Reference is also in this collection.

Abrahams MR, Anderson JA, Giorgi EE, Seoighe C, Mlisana K, Ping LH, Athreya GS, Treurnicht FK, Keele BF, Wood N, et al. 2009. Quantitating the multiplicity of infection with human immunodeficiency virus type 1 subtype $C$ reveals a non-poisson distribution of transmitted variants. J Virol 83: 3556-3567.

Alexander M, Lynch R, Mulenga J, Allen S, Derdeyn CA, Hunter E. 2010. Donor and recipient envs from heterosexual human immunodeficiency virus subtype $C$ transmission pairs require high receptor levels for entry. J Virol 84: $4100-4104$.

Arthos J, Cicala C, Martinelli E, Macleod K, Van Ryk D, Wei D, Xiao Z, Veenstra TD, Conrad TP, Lempicki RA, et al. 2008. HIV-1 envelope protein binds to and signals through integrin $\alpha 4 \beta 7$, the gut mucosal homing receptor for peripheral T cells. Nat Immunol 9: 301-309.

Asmal M, Hellmann I, Liu W, Keele BF, Perelson AS, Bhattacharya T, Gnanakaran S, Daniels M, Haynes BF, Korber BT. 2011. A signature in HIV-1 envelope leader peptide associated with transition from acute to chronic 
G.M. Shaw and E. Hunter

infection impacts envelope processing and infectivity. PLoS One 6: e23673.

Auvert B, Taljaard D, Lagarde E, Sobngwi-Tambekou J, Sitta R, Puren A. 2005. Randomized, controlled intervention trial of male circumcision for reduction of HIV infection risk: The ANRS 1265 trial. PLoS Med 2: e298.

Bailey RC, Moses S, Parker CB, Agot K, Maclean I, Krieger JN, Williams CF, Campbell RT, Ndinya-Achola JO. 2007. Male circumcision for HIV prevention in young men in Kisumu, Kenya: A randomised controlled trial. Lancet 369: 643-656.

Bar KJ, Li H, Chamberland A, Tremblay C, Routy JP, Grayson T, Sun C, Wang S, Learn GH, Morgan CJ, et al. 2010. Wide variation in the multiplicity of HIV-1 infection among injection drug users. J Virol 84: 6241-6247.

Berger EA, Murphy PM, Farber JM. 1999. Chemokine receptors as HIV-1 coreceptors: Roles in viral entry, tropism, and disease. Annu Rev Immunol 17: 657-700.

Boggiano C, Littman DR. 2007. HIV's vagina travelogue. Immunity 26: 145-147.

Boggiano C, Manel N, Littman DR. 2007. Dendritic cellmediated trans-enhancement of human immunodeficiency virus type 1 infectivity is independent of DCSIGN. J Virol 81: 2519-2523.

Boily MC, Baggaley RF, Wang L, Masse B, White RG, Hayes RJ, Alary M. 2009. Heterosexual risk of HIV-1 infection per sexual act: Systematic review and meta-analysis of observational studies. Lancet Infect Dis 9: 118-129.

Brenchley JM, Schacker TW, Ruff LE, Price DA, Taylor JH, Beilman GJ, Nguyen PL, Khoruts A, Larson M, Haase AT, et al. 2004. $\mathrm{CD}^{+}{ }^{+} \mathrm{T}$ cell depletion during all stages of HIV disease occurs predominantly in the gastrointestinal tract. J Exp Med 200: 749-759.

Brenner BG, Roger M, Routy JP, Moisi D, Ntemgwa M, Matte C, Baril JG, Thomas R, Rouleau D, Bruneau J, et al. 2007. High rates of forward transmission events after acute/early HIV-1 infection. J Infect Dis 195: 951959.

Buffa V, Stieh D, Mamhood N, Hu Q, Fletcher P, Shattock RJ. 2009. Cyanovirin-N potently inhibits human immunodeficiency virus type 1 infection in cellular and cervical explant models. J Gen Virol 90: 234-243.

Chohan B, Lang D, Sagar M, Korber B, Lavreys L, Richardson B, Overbaugh J. 2005. Selection for human immunodeficiency virus type 1 envelope glycosylation variants with shorter V1-V2 loop sequences occurs during transmission of certain genetic subtypes and may impact viral RNA levels. J Virol 79: 6528-6531.

Church JD, Huang W, Mwatha A, Musoke P, Jackson JB, Bagenda D, Omer SB, Donnell D, Nakabiito C, Eure C, et al. 2010. Analysis of HIV tropism in Ugandan infants. Curr HIV Res 8: 498-503.

Cicala C, Martinelli E, McNally JP, Goode DJ, Gopaul R, Hiatt J, Jelicic K, Kottilil S, Macleod K, O'Shea A, et al. 2009. The integrin $\alpha 4 \beta 7$ forms a complex with cellsurface CD4 and defines a T-cell subset that is highly susceptible to infection by HIV-1. Proc Natl Acad Sci 106: 20877-20882.

Clark SJ, Saag MS, Decker WD, Campbell-Hill S, Roberson JL, Veldkamp PJ, Kappes JC, Hahn BH, Shaw GM. 1991. High titers of cytopathic virus in plasma of patients with symptomatic primary HIV-1 infection. NEngl J Med 324: 954-960.

Clayton F, Snow G, Reka S, Kotler DP. 1997. Selective depletion of rectal lamina propria rather than lymphoid aggregate CD4 lymphocytes in HIV infection. Clin Exp Immunol 107: 288-292.

Cohen MS, Shaw GM, McMichael AJ, Haynes BF. 2011a. Acute HIV-1 infection-basic, clinical, and public health perspectives. N Engl J Med 364: 1943-1954.

Cohen MS, Chen YQ, McCauley M, Gamble T, Hosseinipour MC, Kumarasamy N, Hakim JG, Kumwenda J, Grinsztejn B, Pilotto JHS. 2011b. Prevention of HIV-1 infection with early antiretroviral therapy. $N$ Engl J Med 365: 493-505.

Collins KB, Patterson BK, Naus GJ, Landers DV, Gupta P. 2000. Development of an in vitro organ culture model to study transmission of HIV-1 in the female genital tract. Nat Med 6: 475-479.

Cummins JE Jr, Guarner J, Flowers L, Guenthner PC, Bartlett J, Morken T, Grohskopf LA, Paxton L, Dezzutti CS. 2007. Preclinical testing of candidate topical microbicides for anti-human immunodeficiency virus type 1 activity and tissue toxicity in a human cervical explant culture. Antimicrob Agents Chemother 51: 1770-1779.

Damond F, Avettand-Fenoel V, Collin G, Roquebert B, Plantier JC, Ganon A, Sizmann D, Babiel R, Glaubitz J, Chaix ML, et al. 2010. Evaluation of an upgraded version of the Roche Cobas AmpliPrep/Cobas TaqMan HIV-1 test for HIV-1 load quantification. J Clin Microbiol 48: 1413-1416.

Derdeyn CA, Decker JM, Bibollet-Ruche F, Mokili JL, Muldoon M, Denham SA, Heil ML, Kasolo F, Musonda R, Hahn BH, et al. 2004. Envelope-constrained neutralization-sensitive HIV-1 after heterosexual transmission. Science 303: 2019-2022.

Dinh MH, Fahrbach KM, Hope TJ. 2011. The role of the foreskin in male circumcision: An evidence-based review. Am J Reprod Immunol 65: 279-283.

Dunkle KL, Stephenson R, Karita E, Chomba E, Kayitenkore K, Vwalika C, Greenberg L, Allen S. 2008. New heterosexually transmitted HIV infections in married or cohabiting couples in urban Zambia and Rwanda: An analysis of survey and clinical data. Lancet 371: 2183-2191.

Edwards JN, Morris HB. 1985. Langerhans' cells and lymphocyte subsets in the female genital tract. Br J Obstet Gynaecol 92: 974-982.

El-Sadr WM, Mayer KH, Hodder SL. 2010. AIDS in America-forgotten but not gone. $N$ Engl J Med 362: 967-970.

Eshleman SH, Khaki L, Laeyendecker O, Piwowar-Manning E, Johnson-Lewis L, Husnik M, Koblin B, Coates T, Chesney M, Vallari A, et al. 2009. Detection of individuals with acute HIV-1 infection using the ARCHITECT HIVAg/ $\mathrm{Ab}$ Combo assay. I Acquir Immune Defic Syndr 52: $121-124$.

Fideli US, Allen SA, Musonda R, Trask S, Hahn BH, Weiss H, Mulenga J, Kasolo F, Vermund SH, Aldrovandi GM. 2001. Virologic and immunologic determinants of heterosexual transmission of human immunodeficiency virus type 1 in Africa. AIDS Res Hum Retroviruses 17: 901-910.

Fiebig EW, Wright DJ, Rawal BD, Garrett PE, Schumacher RT, Peddada L, Heldebrant C, Smith R, Conrad A, Kleinman SH, et al. 2003. Dynamics of HIV viremia and 
antibody seroconversion in plasma donors: Implications for diagnosis and staging of primary HIV infection. AIDS 17: $1871-1879$.

Fischer W, Ganusov VV, Giorgi EE, Hraber PT, Keele BF, Leitner T, Han CS, Gleasner CD, Green L, Lo CC, et al. 2010. Transmission of single HIV-1 genomes and dynamics of early immune escape revealed by ultra-deep sequencing. PLoS One 5: e12303.

Fischetti L, Barry SM, Hope TJ, Shattock RJ. 2009. HIV-1 infection of human penile explant tissue and protection by candidate microbicides. AIDS 23: 319-328.

Fletcher P, Kiselyeva Y, Wallace G, Romano J, Griffin G, Margolis L, Shattock R. 2005. The nonnucleoside reverse transcriptase inhibitor UC-781 inhibits human immunodeficiency virus type 1 infection of human cervical tissue and dissemination by migratory cells. J Virol 79: 11179-11186.

Fletcher PS, Elliott J, Grivel JC, Margolis L, Anton P, McGowan I, Shattock RJ. 2006. Ex vivo culture of human colorectal tissue for the evaluation of candidate microbicides. AIDS 20: 1237-1245.

Frost SD, Liu Y, Pond SL, Chappey C, Wrin T, Petropoulos CJ, Little SJ, Richman DD. 2005. Characterization of human immunodeficiency virus type 1 (HIV-1) envelope variation and neutralizing antibody responses during transmission of HIV-1 subtype B. J Virol 79: 6523-6527.

Gaines H, von Sydow M, Pehrson PO, Lundbegh P. 1988. Clinical picture of primary HIV infection presenting as a glandular-fever-like illness. BMJ 297: 1363-1368.

Galvin SR, Cohen MS. 2004. The role of sexually transmitted diseases in HIV transmission. Nat Rev Microbiol 2: $33-42$.

Gilbert MT, Rambaut A, Wlasiuk G, Spira TJ, Pitchenik AE, Worobey M. 2007. The emergence of HIV/AIDS in the Americas and beyond. Proc Natl Acad Sci 104: 18566-18570.

Gnanakaran S, Bhattacharya T, Daniels M, Keele BF, Hraber PT, Lapedes AS, Shen T, Gaschen B, Krishnamoorthy M, Li H, Decker JM. 2011. Recurrent signature patterns in HIV-1 B clade envelope glycoproteins associated with either early or chronic infections. PloS Pathog 7: e1002209.

Gray RH, Wawer MJ, Brookmeyer R, Sewankambo NK, Serwadda D, Wabwire-Mangen F, Lutalo T, Li X, vanCott T, Quinn TC. 2001. Probability of HIV-1 transmission per coital act in monogamous, heterosexual, HIV-1-discordant couples in Rakai, Uganda. Lancet 357: 1149-1153.

Gray RH, Li X, Kigozi G, Serwadda D, Brahmbhatt H, Wabwire-Mangen F, Nalugoda F, Kiddugavu M, Sewankambo N, Quinn TC, et al. 2005. Increased risk of incident HIV during pregnancy in Rakai, Uganda: A prospective study. Lancet 366: 1182-1188.

Gray RH, Kigozi G, Serwadda D, Makumbi F, Watya S, Nalugoda F, Kiwanuka N, Moulton LH, Chaudhary MA, Chen MZ, et al. 2007. Male circumcision for HIV prevention in men in Rakai, Uganda: A randomised trial. Lancet 369: 657-666.

Greenhead P, Hayes P, Watts PS, Laing KG, Griffin GE, Shattock RJ. 2000. Parameters of human immunodeficiency virus infection of human cervical tissue and inhibition by vaginal virucides. J Virol 74: 5577-5586.
Grivel JC, Elliott J, Lisco A, Biancoto A, Condack C, Shattock RJ, McGowan I, Margolis L, Anton P. 2007. HIV-1 pathogenesis differs in rectosigmoid and tonsillar tissues infected ex vivo with CCR5- and CXCR4-tropic HIV-1. AIDS 21: 1263-1272.

Grobler J, Gray CM, Rademeyer C, Seoighe C, Ramjee G, Karim SA, Morris L, Williamson C. 2004. Incidence of HIV-1 dual infection and its association with increased viral load set point in a cohort of HIV-1 subtype Cinfected female sex workers. J Infect Dis 190: 1355-1359.

Guadalupe M, Reay E, Sankaran S, Prindiville T, Flamm J, McNeil A, Dandekar S. 2003. Severe CD4 ${ }^{+}$T-cell depletion in gut lymphoid tissue during primary human immunodeficiency virus type 1 infection and substantial delay in restoration following highly active antiretroviral therapy. J Virol 77: 11708-11717.

Haaland RE, Hawkins PA, Salazar-Gonzalez J, Johnson A, Tichacek A, Karita E, Manigart O, Mulenga J, Keele BF, Shaw GM, et al. 2009. Inflammatory genital infections mitigate a severe genetic bottleneck in heterosexual transmission of subtype A and C HIV-1. PLoS Pathog 5: e1000274.

Haase AT. 2010. Targeting early infection to prevent HIV-1 mucosal transmission. Nature 464: 217-223.

Heise C, Miller CJ, Lackner A, Dandekar S. 1994. Primary acute simian immunodeficiency virus infection of intestinal lymphoid tissue is associated with gastrointestinal dysfunction. J Infect Dis 169: 1116-1120.

Hemelaar J, Gouws E, Ghys PD, Osmanov S. 2006. Global and regional distribution of HIV-1 genetic subtypes and recombinants in 2004. AIDS 20: W13-W23.

Hessell AJ, Hangartner L, Hunter M, Havenith CE, Beurskens FJ, Bakker JM, Lanigan CM, Landucci G, Forthal DN, Parren PW, et al. 2007. Fc receptor but not complement binding is important in antibody protection against HIV. Nature 449: 101-104.

Hessell AJ, Poignard P, Hunter M, Hangartner L, Tehrani DM, Bleeker WK Parren PW, Marx PA, Burton DR. 2009a. Effective, low-titer antibody protection against low-dose repeated mucosal SHIV challenge in macaques. Nat Med 15: 951-954.

Hessell AJ, Rakasz EG, Poignard P, Hangartner L, Landucci G, Forthal DN, Koff WC, Watkins DI, Burton DR. 2009b. Broadly neutralizing human anti-HIV antibody 2 G12 is effective in protection against mucosal SHIV challenge even at low serum neutralizing titers. PLoS Pathog 5: e1000433.

Hladik F, McElrath MJ. 2008. Setting the stage: Host invasion by HIV. Nat Rev Immunol 8: 447-457.

Hladik F, Sakchalathorn P, Ballweber L, Lentz G, Fialkow M, Eschenbach D, McElrath MJ. 2007. Initial events in establishing vaginal entry and infection by human immunodeficiency virus type-1. Immunity 26: 257-270.

Hu J, Gardner MB, Miller CJ. 2000. Simian immunodeficiency virus rapidly penetrates the cervicovaginal mucosa after intravaginal inoculation and infects intraepithelial dendritic cells. J Virol 74: 6087-6095.

Hu Q, Frank I, Williams V, Santos JJ, Watts P, Griffin GE, Moore JP, Pope M, Shattock RJ. 2004. Blockade of attachment and fusion receptors inhibits HIV-1 infection of human cervical tissue. J Exp Med 199: 1065-1075. 
G.M. Shaw and E. Hunter

Hudgens MG, Longini IM Jr, Vanichseni S, Hu DJ, Kitayaporn D, Mock PA, Halloran ME, Satten GA, Choopanya K, Mastro TD. 2002. Subtype-specific transmission probabilities for human immunodeficiency virus type 1 among injecting drug users in Bangkok, Thailand. Am J Epidemiol 155: 159-168.

Isaacman-Beck J, Hermann EA, Yi Y, Ratcliffe SJ, Mulenga J, Allen S, Hunter E, Derdeyn CA, Collman RG. 2009. Heterosexual transmission of human immunodeficiency virus type 1 subtype C: Macrophage tropism, alternative coreceptor use, and the molecular anatomy of CCR 5 utilization. J Virol 83: 8208-8220.

Jensen MA, Li FS, van 't Wout AB, Nickle DC, Shriner D, He HX, McLaughlin S, Shankarappa R, Margolick JB, Mullins JI. 2003. Improved coreceptor usage prediction and genotypic monitoring of R5-to-X4 transition by motif analysis of human immunodeficiency virus type $1 \mathrm{env}$ V3 loop sequences. J Virol 77: 13376-13388.

Kader M, Wang X, Piatak M, Lifson J, Roederer M, Veazey R, Mattapallil JJ. 2009. $\alpha 4^{+} \beta 7$ (hi)CD $4^{+}$memory $\mathrm{T}$ cells harbor most Th-17 cells and are preferentially infected during acute SIV infection. Mucosal Immunol 2: 439449.

Kearney M, Maldarelli F, Shao W, Margolick JB, Daar ES, Mellors JW, Rao V, Coffin JM, Palmer S. 2009. Human immunodeficiency virus type 1 population genetics and adaptation in newly infected individuals. J Virol 83: $2715-2727$.

Keele BF, Giorgi EE, Salazar-Gonzalez JF, Decker JM, Pham KT, Salazar MG, Sun C, Grayson T, Wang S, Li H, et al. 2008. Identification and characterization of transmitted and early founder virus envelopes in primary HIV-1 infection. Proc Natl Acad Sci 105: 7552-7557.

Keele BF, Li H, Learn GH, Hraber P, Giorgi EE, Grayson T, Sun C, Chen Y, Yeh WW, Letvin NL, et al. 2009. Low-dose rectal inoculation of rhesus macaques by SIVsmE660 or SIVmac251 recapitulates human mucosal infection by HIV-1. J Exp Med 206: 1117-1134.

Korber B, Muldoon M, Theiler J, Gao F, Gupta R, Lapedes A, Hahn BH, Wolinsky S, Bhattacharya T. 2000. Timing the ancestor of the HIV-1 pandemic strains. Science 288: 1789-1796.

Kotler DP, Gaetz HP, Lange M, Klein EB, Holt PR. 1984. Enteropathy associated with the acquired immunodeficiency syndrome. Ann Intern Med 101: 421-428.

Kouyos RD, von Wyl V, Yerly S, Boni J, Taffe P, Shah C, Burgisser P, Klimkait T, Weber R, Hirschel B, et al. 2010. Molecular epidemiology reveals long-term changes in HIV type 1 subtype B transmission in Switzerland. Infect Dis 201: 1488-1497.

Learn GH, Muthui D, Brodie SJ, Zhu T, Diem K, Mullins JI, Corey L. 2002. Virus population homogenization following acute human immunodeficiency virus type 1 infection. J Virol 76: 11953-11959.

Lee HY, Giorgi EE, Keele BF, Gaschen B, Athreya GS, SalazarGonzalez JF, Pham KT, Goepfert PA, Kilby JM, Saag MS, et al. 2009. Modeling sequence evolution in acute HIV-1 infection. J Theor Biol 261: 341-360.

Li M, Gao F, Mascola JR, Stamatatos L, Polonis VR, Koutsoukos M, Voss G, Goepfert P, Gilbert P, Greene KM, et al. 2005a. Human immunodeficiency virus type 1 env clones from acute and early subtype B infections for standardized assessments of vaccine-elicited neutralizing antibodies. J Virol 79: 10108-10125.

Li Q, Duan L, Estes JD, Ma ZM, Rourke T, Wang Y, Reilly C, Carlis J, Miller CJ, Haase AT. 2005b. Peak SIV replication in resting memory $\mathrm{CD} 4^{+} \mathrm{T}$ cells depletes gut lamina propria CD4 ${ }^{+} \mathrm{T}$ cells. Nature 434: 1148-1152.

Li M, Salazar-Gonzalez JF, Derdeyn CA, Morris L, Williamson C, Robinson JE, Decker JM, Li Y, Salazar MG, Polonis VR, et al. 2006. Genetic and neutralization properties of subtype Chuman immunodeficiency virus type 1 molecular env clones from acute and early heterosexually acquired infections in Southern Africa. J Virol 80: $11776-11790$

Li Q, Estes JD, Duan L, Jessurun J, Pambuccian S, Forster C, Wietgrefe S, Zupancic M, Schacker T, Reilly C, et al. 2008. Simian immunodeficiency virus-induced intestinal cell apoptosis is the underlying mechanism of the regenerative enteropathy of early infection. J Infect Dis 197: 420-429.

Li Q, Estes JD, Schlievert PM, Duan L, Brosnahan AJ, Southern PJ, Reilly CS, Peterson ML, Schultz-Darken N, Brunner KG, et al. 2009a. Glycerol monolaurate prevents mucosal SIV transmission. Nature 458: 1034-1038.

Li Q, Smith AJ, Schacker TW, Carlis JV, Duan L, Reilly CS, Haase AT. 2009b. Microarray analysis of lymphatic tissue reveals stage-specific, gene expression signatures in HIV-1 infection. J Immunol 183: 1975-1982.

Li H, Bar KJ, Wang S, Decker JM, Chen Y, Sun C, SalazarGonzalez JF, Salazar MG, Learn GH, Morgan CJ, et al. 2010. High multiplicity infection by HIV-1 in men who have sex with men. PLoS Pathog 6: e1000890.

Lifson JD, Nowak MA, Goldstein S, Rossio JL, Kinter A, Vasquez G, Wiltrout TA, Brown C, Schneider D, Wahl L, et al. 1997. The extent of early viral replication is a critical determinant of the natural history of simian immunodeficiency virus infection. J Virol 71: 9508-9514.

Lindback S, Karlsson AC, Mittler J, Blaxhult A, Carlsson M, Briheim G, Sonnerborg A, Gaines H. 2000a. Viral dynamics in primary HIV-1 infection. Karolinska Institutet Primary HIV Infection Study Group. AIDS 14: 2283-2291.

Lindback S, Thorstensson R, Karlsson AC, von Sydow M, Flamholc L, Blaxhult A, Sonnerborg A, Biberfeld G, Gaines H. 2000b. Diagnosis of primary HIV-1 infection and duration of follow-up after HIV exposure. Karolinska Institute Primary HIV Infection Study Group. AIDS 14: 2333-2339.

Little SJ, McLean AR, Spina CA, Richman DD, Havlir DV. 1999. Viral dynamics of acute HIV-1 infection. J Exp Med 190: 841-850.

Liu J, Keele BF, Li H, Keating S, Norris PJ, Carville A, Mansfield KG, Tomaras GD, Haynes BF, Kolodkin-Gal D, et al. 2010. Low-dose mucosal simian immunodeficiency virus infection restricts early replication kinetics and transmitted virus variants in rhesus monkeys. J Virol 84: 1040610412.

Long EM, Martin HL Jr, Kreiss JK, Rainwater SM, Lavreys L, Jackson DJ, Rakwar J, Mandaliya K, Overbaugh J. 2000. Gender differences in HIV-1 diversity at time of infection. Nat Med 6: 71-75.

Ma Z, Lu FX, Torten M, Miller CJ. 2001. The number and distribution of immune cells in the cervicovaginal 
mucosa remain constant throughout the menstrual cycle of rhesus macaques. Clin Immunol 100: 240-249.

Ma Z-M, Stone M, Piatak M Jr, Schweighardt B, Haigwood NL, Montefiori D, Lifson JD, Busch MP, Miller CJ. 2009. High specific infectivity of plasma virus from the pre-ramp-up and ramp-up stages of acute simian immunodeficiency virus infection. J Virol 83: 3288-3297.

Ma Z-M, Keele BF, Qureshi H, Stone M, DeSilva V, Fritts L, Lifson JD, Miller CJ. 2011. SIVmac251 is inefficiently transmitted to rhesus macaques by penile inoculation with a single SIVenv variant found in ramp-up phase plasma. AIDS Res Hum Retroviruses doi: 10.1089/aid. 2011.0090

Maher D, Wu X, Schacker T, Horbul J, Southern P. 2005. HIV binding, penetration, and primary infection in human cervicovaginal tissue. Proc Natl Acad Sci 102: 11504-11509.

* Malim MH, Bieniasz PD. 2011. HIV restriction factors and mechanisms of evasion. Cold Spring Harb Perspect Med doi: 10.1101/cshperspect.a006940.

Mascola JR. 2002. Passive transfer studies to elucidate the role of antibody-mediated protection against HIV-1. Vaccine 20: 1922-1925.

Masharsky AE, Dukhovlinova EN, Verevochkin SV, Toussova OV, Skochilov RV, Anderson JA, Hoffman I, Cohen MS, Swanstrom R, Kozlov AP. 2010. A substantial transmission bottleneck among newly and recently HIV-1infected injection drug users in St Petersburg, Russia. $J$ Infect Dis 201: 1697-1702.

Mattapallil JJ, Douek DC, Hill B, Nishimura Y, Martin M, Roederer M. 2005. Massive infection and loss of memory $\mathrm{CD}^{+} \mathrm{T}$ cells in multiple tissues during acute SIV infection. Nature 434: 1093-1097.

McElrath MJ, De Rosa SC, Moodie Z, Dubey S, Kierstead L, Janes H, Defawe OD, Carter DK, Hural J, Akondy R, et al. 2008. HIV-1 vaccine-induced immunity in the test-ofconcept step study: A case-cohort analysis. Lancet 372: 1894-1905.

Mehandru S, Poles MA, Tenner-Racz K, Horowitz A, Hurley A, Hogan C, Boden D, Racz P, Markowitz M. 2004. Primary HIV-1 infection is associated with preferential depletion of $\mathrm{CD}^{+} \mathrm{T}$ lymphocytes from effector sites in the gastrointestinal tract. J Exp Med 200: 761-770.

Merbah M, Introini A, Fitzgerald W, Grivel JC, Lisco A, Vanpouille C, Margolis L. 2011. Cervico-vaginal tissue ex vivo as a model to study early events in HIV-1 infection. Am J Reprod Immunol 65: 268-278.

Miller CJ, Li Q, Abel K, Kim EY, Ma ZM, Wietgrefe S, La Franco-Scheuch L, Compton L, Duan L, Shore MD, et al. 2005. Propagation and dissemination of infection after vaginal transmission of simian immunodeficiency virus. J Virol 79: 9217-9227.

Miller WC, Rosenberg NE, Rutstein SE, Powers KA. 2010. Role of acute and early HIV infection in the sexual transmission of HIV. Curr Opin HIVAIDS 5: 277-282.

Miyake A, Ibuki K, Enose Y, Suzuki H, Horiuchi R, Motohara M, Saito N, Nakasone T, Honda M, Watanabe T, et al. 2006. Rapid dissemination of a pathogenic simian/human immunodeficiency virus to systemic organs and active replication in lymphoid tissues following intrarectal infection. J Gen Virol 87: 1311-1320.
Nawaz F, Cicala C, Van Ryk D, Block KE, Jelicic K, McNally JP, Ogundare O, Pascuccio M, Patel N, Wei D, et al. 2011. The genotype of early-transmitting HIV gp120s promotes $\alpha \beta$-reactivity, revealing $\alpha \beta C D 4^{+}$T cells as key targets in mucosal transmission. PLoS Pathog 7: e1001301.

Nowak MA, Lloyd AL, Vasquez GM, Wiltrout TA, Wahl LM, Bischofberger N, Williams J, Kinter A, Fauci AS, Hirsch VM, et al. 1997. Viral dynamics of primary viremia and antiretroviral therapy in simian immunodeficiency virus infection. J Virol 71: 7518-7525.

Nugent CT, Dockter J, Bernardin F, Hecht R, Smith D, Delwart E, Pilcher C, Richman D, Busch M, Giachetti C. 2009. Detection of HIV-1 in alternative specimen types using the APTIMA HIV-1 RNA Qualitative Assay. J Virol Methods 159: 10-14.

Palmer S, Wiegand AP, Maldarelli F, Bazmi H, Mican JM, Polis M, Dewar RL, Planta A, Liu S, Metcalf JA, et al. 2003. New real-time reverse transcriptase-initiated PCR assay with single-copy sensitivity for human immunodeficiency virus type 1 RNA in plasma. J Clin Microbiol 41: 4531-4536.

Pearson JE, Krapivsky P, Perelson AS. 2011. Stochastic theory of early viral infection: Continuous versus burst production of virions. PLoS Comput Biol 7: e1001058.

Pope M, Haase AT. 2003. Transmission, acute HIV-1 infection and the quest for strategies to prevent infection. Nat Med 9: 847-852.

Poss M, Martin HL, Kreiss JK, Granville L, Chohan B, Nyange P, Mandaliya K, Overbaugh J. 1995. Diversity in virus populations from genital secretions and peripheral blood from women recently infected with human immunodeficiency virus type 1. J Virol 69: 8118-8122.

Powers KA, Poole C, Pettifor AE, Cohen MS. 2008. Rethinking the heterosexual infectivity of HIV-1: A systematic review and meta-analysis. Lancet Infect Dis 8: 553-563.

Pudney J, Quayle AJ, Anderson DJ. 2005. Immunological microenvironments in the human vagina and cervix: Mediators of cellular immunity are concentrated in the cervical transformation zone. Biol Reprod 73: 1253-1263.

Quinn TC. 2007. Circumcision and HIV transmission. Curr Opin Infect Dis 20: 33-38.

Quinn TC, Wawer MJ, Sewankambo N, Serwadda D, Li C, Wabwire-Mangen F, Meehan MO, Lutalo T, Gray RH. 2000. Viral load and heterosexual transmission of human immunodeficiency virus type 1. Rakai Project Study Group. N Engl J Med 342: 921-929.

Resch W, Hoffman N, Swanstrom R. 2001. Improved success of phenotype prediction of the human immunodeficiency virus type 1 from envelope variable loop 3 sequence using neural networks. Virology 288: 51-62.

Ribeiro RM, Qin L, Chavez LL, Li D, Self SG, Perelson AS. 2010. Estimation of the initial viral growth rate and basic reproductive number during acute HIV-1 infection. J Virol 84: 6096-6102.

Richman DD, Wrin T, Little SJ, Petropoulos CJ. 2003. Rapid evolution of the neutralizing antibody response to HIV type 1 infection. Proc Natl Acad Sci 100: 4144-4149.

Ridzon R, Gallagher K, Ciesielski C, Ginsberg MB, Robertson BJ, Luo CC, DeMaria A Jr, 1997. Simultaneous transmission of human immunodeficiency virus and hepatitis C virus from a needle-stick injury. $N$ Engl J Med 336: 919-922. 
G.M. Shaw and E. Hunter

Ritola K, Pilcher CD, Fiscus SA, Hoffman NG, Nelson JA, Kitrinos KM, Hicks CB, Eron JJ Jr, Swanstrom R. 2004. Multiple V1/V2 env variants are frequently present during primary infection with human immunodeficiency virus type 1. J Virol 78: 11208-11218.

Russell ES, Kwiek JJ, Keys J, Barton K, Mwapasa V, Montefiori DC, Meshnick SR, Swanstrom R. 2011. The genetic bottleneck in vertical transmission of subtype C HIV-1 is not driven by selection of especially neutralizationresistant virus from the maternal viral population. J Virol 85: 8253-8262.

Saba E, Grivel JC, Vanpouille C, Brichacek B, Fitzgerald W, Margolis L, Lisco A. 2010. HIV-1 sexual transmission: Early events of HIV-1 infection of human cervico-vaginal tissue in an optimized ex vivo model. Mucosal Immuno 3: $280-290$.

Sacktor N, Nakasujja N, Skolasky RL, Rezapour M, Robertson K, Musisi S, Katabira E, Ronald A, Clifford DB, Laeyendecker O, et al. 2009. HIV subtype D is associated with dementia, compared with subtype A, in immunosuppressed individuals at risk of cognitive impairment in Kampala, Uganda. Clin Infect Dis 49: 780-786.

Sagar M, Kirkegaard E, Long EM, Celum C, Buchbinder S, Daar ES, Overbaugh J. 2004. Human immunodeficiency virus type 1 (HIV-1) diversity at time of infection is not restricted to certain risk groups or specific HIV-1 subtypes. J Virol 78: 7279-7283.

Sagar M, Laeyendecker O, Lee S, Gamiel J, Wawer MJ, Gray RH, Serwadda D, Sewankambo NK, Shepherd JC, Toma J, et al. 2009. Selection of HIV variants with signature genotypic characteristics during heterosexual transmission. J Infect Dis 199: 580-589.

Salazar-Gonzalez JF, Bailes E, Pham KT, Salazar MG, Guffey MB, Keele BF, Derdeyn CA, Farmer P, Hunter E, Allen S, et al. 2008. Deciphering human immunodeficiency virus type 1 transmission and early envelope diversification by single-genome amplification and sequencing. J Virol 82: 3952-3970.

Salazar-Gonzalez JF, Salazar MG, Keele BF, Learn GH, Giorgi EE, Li H, Decker JM, Wang S, Baalwa J, Kraus $\mathrm{MH}$, et al. 2009. Genetic identity, biological phenotype, and evolutionary pathways of transmitted/founder viruses in acute and early HIV-1 infection. J Exp Med 206: 1273-1289.

Schacker T, Collier AC, Hughes J, Shea T, Corey L. 1996. Clinical and epidemiologic features of primary HIV infection. Ann Intern Med 125: 257-264.

Schacker T, Little S, Connick E, Gebhard K, Zhang ZQ, Krieger J, Pryor J, Havlir D, Wong JK, Schooley RT, et al. 2001. Productive infection of T cells in lymphoid tissues during primary and early human immunodeficiency virus infection. J Infect Dis 183: 555-562.

* Sharp PM, Hahn BH. 2011. Origins of HIV and the AIDS pandemic. Cold Spring Harbor Perspect Med doi: 10.1101 cshperspect.a006841.

Shen R, Richter HE, Clements RH, Novak L, Huff K, Bimczok D, Sankaran-Walters S, Dandekar S, Clapham PR, Smythies LE, et al. 2009. Macrophages in vaginal but not intestinal mucosa are monocyte-like and permissive to human immunodeficiency virus type 1 infection. Virol 83: 3258-3267.
Shen R, Smythies LE, Clements RH, Novak L, Smith PD. 2010. Dendritic cells transmit HIV-1 through human small intestinal mucosa. J Leukoc Biol 87: 663-670.

Stone M, Keele BF, Ma ZM, Bailes E, Dutra J, Hahn BH, Shaw GM, Miller CJ. 2010. A limited number of simian immunodeficiency virus (SIV) env variants are transmitted to rhesus macaques vaginally inoculated with SIVmac251. J Virol 84: 7083-7095.

Taylor BS, Sobieszczyk ME, McCutchan FE, Hammer SM. 2008. The challenge of HIV-1 subtype diversity. N Engl J Med 358: 1590-1602.

UNAIDS. 2010. Global Report 2010, Geneva. http://www. unaids.org/globalreport/documents/20101123_Global Report_full_en.pdf.

Veazey RS, DeMaria M, Chalifoux LV, Shvetz DE, Pauley DR, Knight HL, Rosenzweig M, Johnson RP, Desrosiers RC, Lackner AA. 1998. Gastrointestinal tract as a major site of $\mathrm{CD}^{+}{ }^{+} \mathrm{T}$ cell depletion and viral replication in SIV infection. Science 280: 427-431.

Wawer MJ, Gray RH, Sewankambo NK, Serwadda D, Li X, Laeyendecker O, Kiwanuka N, Kigozi G, Kiddugavu M, Lutalo T, et al. 2005. Rates of HIV-1 transmission per coital act, by stage of HIV-1 infection, in Rakai, Uganda. $J$ Infect Dis 191: 1403-1409.

Wei X, Decker JM, Wang S, Hui H, Kappes JC, Wu X, Salazar-Gonzalez JF, Salazar MG, Kilby JM, Saag MS, et al. 2003. Antibody neutralization and escape by HIV-1. Nature 422: 307-312.

Wilen CB, Parrish NF, Pfaff JM, Decker JM, Henning EA, Haim H, Sodroski J, Haynes BF, Montefiori DC, Tilton JC, et al. 2011a. Phenotypic and immunologic comparison of clade B transmitted/founder and chronic HIV-1 envelope glycoproteins. J Virol (in press).

* Wilen CB, Tilton JC, Doms RW. 2011b. Cell binding and entry. Cold Spring Harbor Perspect Med doi: 10.1101/ cshperspect.a006866.

Wira CR, Veronese F. 2011. Sexual transmission of HIV in the 21st century. Am J Reprod Immunol 65: 181-376.

Wolfs TF, Zwart G, Bakker M, Goudsmit J. 1992. HIV-1 genomic RNA diversification following sexual and parenteral virus transmission. Virology 189: 103-110.

Wolinsky SM, Wike CM, Korber BT, Hutto C, Parks WP, Rosenblum LL, Kunstman KJ, Furtado MR, Munoz JL. 1992. Selective transmission of human immunodeficiency virus type-1 variants from mothers to infants. Science 255: 1134-1137.

Worobey M, Gemmel M, Teuwen DE, Haselkorn T, Kunstman K, Bunce M, Muyembe JJ, Kabongo JM, Kalengayi RM, Van Marck E, et al. 2008. Direct evidence of extensive diversity of HIV-1 in Kinshasa by 1960. Nature 455: 661-664.

Yeh WW, Rao SS, Lim S-Y, Zhang J, Hraber PT, Brassard LM, Luedemann C, Todd JP, Dodson A, Shen L. 2011. The TRIM5 gene modulates penile mucosal acquisition of simian immunodeficiency virus in Rhesus monkeys. J Virol 85: 10389-10398.

Zhang LQ, MacKenzie P, Cleland A, Holmes EC, Brown AJ, Simmonds P. 1993. Selection for specific sequences in the external envelope protein of human immunodeficiency virus type 1 upon primary infection. J Virol 67: 33453356. 
Zhang Z, Schuler T, Zupancic M, Wietgrefe S, Staskus KA, Reimann KA, Reinhart TA, Rogan M, Cavert W, Miller CJ, et al. 1999. Sexual transmission and propagation of SIV and HIV in resting and activated $\mathrm{CD}^{+}{ }^{+} \mathrm{T}$ cells. Science 286: $1353-1357$.

Zhang ZQ, Wietgrefe SW, Li Q, Shore MD, Duan L, Reilly C, Lifson JD, Haase AT. 2004. Roles of substrate availability and infection of resting and activated $\mathrm{CD}^{+} \mathrm{T}$ cells in transmission and acute simian immunodeficiency virus infection. Proc Natl Acad Sci 101: 5640-5645.
Zhu T, Mo H, Wang N, Nam DS, Cao Y, Koup RA, Ho DD 1993. Genotypic and phenotypic characterization of HIV-1 patients with primary infection. Science 261: $1179-1181$.

Zhu T, Wang N, Carr A, Nam DS, Moor-Jankowski R, Cooper DA, Ho DD. 1996. Genetic characterization of human immunodeficiency virus type 1 in blood and genital secretions: Evidence for viral compartmentalization and selection during sexual transmission. $J$ Virol 70: $3098-3107$. 


\section{$\&_{\mathrm{CSH}}^{\infty} \&$ Cold Spring Harbor

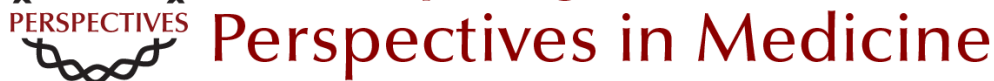

\section{HIV Transmission}

George M. Shaw and Eric Hunter

Cold Spring Harb Perspect Med 2012; doi: 10.1101/cshperspect.a006965 originally published online October 6, 2012

\section{Subject Collection HIV}

HIV Pathogenesis: Dynamics and Genetics of

Viral Populations and Infected Cells John Coffin and Ronald Swanstrom

Human Immunodeficiency Virus Vaccine Trials Robert J. O'Connell, Jerome H. Kim, Lawrence Corey, et al.

HIV Transmission George M. Shaw and Eric Hunter

Novel Cell and Gene Therapies for HIV James A. Hoxie and Carl H. June

\section{Behavioral and Biomedical Combination}

Strategies for HIV Prevention Linda-Gail Bekker, Chris Beyrer and Thomas C. Quinn

HIV-1 Assembly, Budding, and Maturation Wesley I. Sundquist and Hans-Georg Kräusslich

HIV-1 Assembly, Budding, and Maturation Wesley I. Sundquist and Hans-Georg Kräusslich

Lessons in Nonhuman Primate Models for AIDS Vaccine Research: From Minefields to Milestones Jeffrey D. Lifson and Nancy L. Haigwood
HIV-1 Pathogenesis: The Virus

Ronald Swanstrom and John Coffin

The T-Cell Response to HIV

Bruce Walker and Andrew McMichael

HIV-1 Reverse Transcription Wei-Shau Hu and Stephen H. Hughes

HIV Pathogenesis: The Host A.A. Lackner, Michael M. Lederman and Benigno Rodriguez

HIV: Cell Binding and Entry Craig B. Wilen, John C. Tilton and Robert W. Doms

Innate Immune Control of HIV Mary Carrington and Galit Alter

HIV DNA Integration

Robert Craigie and Frederic D. Bushman

HIV-1-Related Central Nervous System Disease: Current Issues in Pathogenesis, Diagnosis, and Treatment Serena Spudich and Francisco González-Scarano

For additional articles in this collection, see http://perspectivesinmedicine.cshlp.org/cgi/collection/ 